\title{
19. LATE CRETACEOUS PALYNOFLORAS (SPOROMORPHS AND DINOCYSTS) FROM THE KERGUELEN PLATEAU, SOUTHERN INDIAN OCEAN (SITES 748 AND 750) ${ }^{1}$
}

\author{
Barbara A.R. Mohr ${ }^{2}$ and Carole T. Gee 2,3
}

\begin{abstract}
Pollen, spore, and dinoflagellate cyst floras of Late Cretaceous age were found at Sites 748 (120-748C-62R through -79R) and 750 (120-750B-11W) of Ocean Drilling Program Leg 120 to the Kerguelen Plateau area in the Southern Indian Ocean. The ranges of dinocyst and sporomorph species indicate ages between the Cenomanian and Coniacian (to possibly the early Santonian). The ratio of marine/terrestrial flora elements is extremely variable, showing a trend from highly terrestrial (up to $\sim 70 \%$ ) in the late Cenomanian to highly marine (up to $90 \%$ ) in the Coniacian/early Santonian. Low sedimentation rates of about $3-5 \mathrm{~cm} / 1000 \mathrm{yr}$ were calculated for the glauconitic sediments of Turonian and Coniacian age at Site 748 (lithologic Subunit IIIB).
\end{abstract}

\section{INTRODUCTION}

The objective of the drilling operations of Leg 120 of the Ocean Drilling Program was to recover expanded Paleogene and Cretaceous sections to document the early sedimentation and tectonic history of the Southern Kerguelen Plateau. This southern part lies at a depth of $1000-3000 \mathrm{~m}$. The depth of the seafloor surrounding the Kerguelen Plateau is generally 4000 $4500 \mathrm{~m}$, except on the feature's northeastern and southern flanks, where depths range from 3000 to $4000 \mathrm{~m}$ toward the Southeast Indian Ridge and the Antarctic continental margin, respectively (Coffin et al., 1990).

Before the drilling campaigns of Legs 119 and 120, only scattered samples derived from piston cores and dredging were available from the Kerguelen Plateau area (Houtz et al., 1977). Seismic profiles that first surveyed the sedimentary filling of such basins as the Raggatt Basin were published as results of French and Australian cruises (Colwell et al., 1988). To succeed in the primary goal of calibrating the seismic stratigraphy, precise dating of the section was necessary. Palynology proved to be a major tool that could provide a stratigraphic framework in the lower part of the deposits overlaying the basaltic basement, as other microfossil groups are missing from the lower part of Sites 748 and 750 . These sites contain expanded Cretaceous sections from the early Albian (120-750B-12R through -14R; Mohr and Gee, this volume) to the Maestrichtian (120-748C-27R; Mao and Mohr, this volume).

Until recently, few palynofloras were known from the early Late Cretaceous of the southern high latitudes. The papers published thus far are concerned mostly with the Australian area and include the classic studies of Deflandre and Cookson (1955) and Cookson and Eisenack (1958, 1960, 1962, 1970, $1974)$ and, more recently, the studies of Norvick and Burger (1976), Harris (1976), Helby et al. (1987), and McMinn (1988). Papers by Dettmann and Thomson (1987) and Olivero and Palamarczuk (1987) report on early Late Cretaceous palynomorph floras from the Antarctic Peninsula area.

\footnotetext{
${ }^{1}$ Wise, S. W., Jr., Schlich, R., et al., 1992. Proc. ODP, Sci. Results, 120 College Station, TX (Ocean Drilling Program).

2 ETH-Zürich, Geological Institute, Sonneggstrasse 12, CH-8092 Zürich, Switzerland.

${ }^{3}$ Present address: University of Bonn, Institute of Paleontology, Nussallee 8, D-5300 Bonn 1, Federal Republic of Germany.
}

Another important aspect of paleobotanical studies on Kerguelen Plateau floras is a historical one. As early as 1857, Hooker mentioned the discovery of fossil wood in a letter to Darwin (Holdgate, 1960). More recently, Cookson (1946, 1947) described the first in situ palynofloras from southern high latitudes, which were found in early Tertiary lignites on Kerguelen Island. She recognized the affinity of the pollen to widespread plant groups characteristic of the Southern Hemisphere today (i.e., to podocarps and Nothofagus, the "southern beech") as well as the importance of fossil plants in understanding their past and present biogeography.

\section{Geographic and Geologic Setting}

Sites 748 and 750 were drilled on the Kerguelen Plateau, which is located in the south-central Indian Ocean between $46^{\circ}$ and $64^{\circ} \mathrm{S}$ (Fig. 1). The plateau can be divided into two distinct domains: the Kerguelen-Heard Plateau to the north, and the volcanic Kerguelen, Heard, and McDonald islands and the Southern Kerguelen Plateau to the south (Houtz et al., $1977)$. The southern part $\left(57^{\circ} \mathrm{S}\right.$ to $\left.64^{\circ} \mathrm{S}\right)$ is deeper, generally lying in water depths between 1500 and $2000 \mathrm{~m}$. It is characterized by several large basement uplifts, that result in a remarkable topography with crests and basins. The best developed sedimentary basin is the Raggatt Basin, east of the Banzare Bank. During the Leg 120 cruise, the total sequence of the sedimentary filling of the Raggatt Basin, including the basaltic basement, was drilled at Sites 748 and 750 .

\section{Sites 748 and $\mathbf{7 5 0}$}

Site 748 is located on the Southern Kerguelen Plateau in the western part of the Raggatt Basin, east of Banzare Bank (approximately $58^{\circ} 26.5^{\prime} \mathrm{S}, 78^{\circ} 59^{\prime} \mathrm{E}$; water depth about 1290 $\mathrm{m})$. Four main lithologic units, ranging from late Pleistocene sediments to Early Cretaceous volcanic basement (Schlich, Wise, et al., 1989), were drilled in Holes 748A, 748B, and $748 \mathrm{C}$. Hole $748 \mathrm{C}$ reached a depth of about $935 \mathrm{~m}$ below seafloor (mbsf) with a total of 87 cores. An extensive description of the upper two lithologic units, from Pleistocene to Paleocene (Sections 120-748B-1H through -22X and Sections $120-748 \mathrm{C}-1 \mathrm{R}$ through -24R) can be found in Schlich, Wise, et al. (1989). Lithologic Unit III (Fig. 2), from which the material for the following study was sampled, consists of Paleogene through Cenomanian sediments. Subunit IIIA (about 390-690 mbsf; Cores $120-748 \mathrm{C}-39 \mathrm{R}$ through $-56 \mathrm{R}$ ) consists of late Paleocene to early Campanian glauconitic rud-, pack-, and 


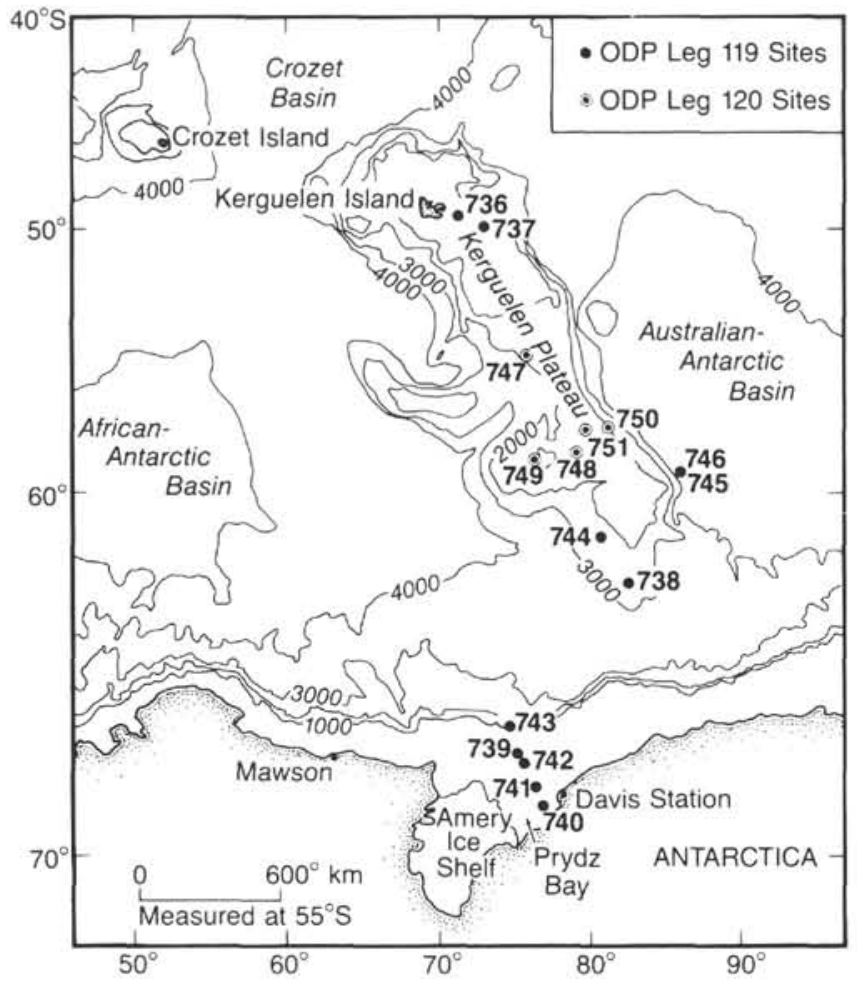

Figure 1. Bathymetric chart of the Kerguelen Plateau showing the locations of Leg 120 sites and previously drilled Leg 119.

grainstones that contain silicified layers and include intervals of abundant bryozoans, inoceramid prisms, and crinoid columnals as well as rare red algal debris. Subunit IIIB (interval: Core 120-748C-57R through Section 120-748C-79R-4, $58 \mathrm{~cm}$; 692.0-897.6 mbsf) consists of Coniacian/basal Santonian to Cenomanian sand, silt, and claystones.

Recovered between Subunit IIIB and the basaltic basement (Unit IV, below $900 \mathrm{mbsf}$ ) was a layer of basalt cobble conglomerate consisting of rounded, altered basalt cobbles and boulders, broken thick-walled mollusc fragments, and a matrix of glauconitic calcareous siltstone (Subunit IIIC; Sections $120-748 \mathrm{C}-79 \mathrm{R}-4,58 \mathrm{~cm}$, to $-79 \mathrm{R}-5,25 \mathrm{~cm}$; 897.6-898.8 mbsf). According to Leclaire et al. (1987), the age of the volcanic basement is estimated at $114 \pm 1 \mathrm{~m} . \mathrm{y}$., which is equivalent to the Aptian (Kent and Gradstein, 1985).

According to Bitschene et al. (this volume), one of the dominant features of the Late Cretaceous sequence (lithologic Unit III) is an enrichment in glauconite pellets, which comprise $10 \%$ to $90 \%$ of the sediment. Lithologic Subunit IIIB exhibits cross bedding and slight to intense bioturbation, but less bioproductivity than in lithologic Subunit IIIA. According to these authors, the concentration of $\mathrm{Cr}$ (bulk sediment) is very high in lithologic Subunit IIIB and is derived from the weathering of volcanic complexes on land and/or submarine. In addition, this subunit is rich in the two land derived components Fe and kaolinite, whereas Subunit IIIA shows the highest input of biogenic carbonate and phosphatic debris.

Site 750 (approximately $57^{\circ} 36^{\prime} \mathrm{S}, 81^{\circ} 15^{\prime} \mathrm{E}$, water depth to $2030.5 \mathrm{~m}$ ) is located in the eastern part of the Raggatt Basin. Holes $750 \mathrm{~A}$ and $750 \mathrm{~B}$ were drilled at this site. In these drill holes, below a $40-\mathrm{cm}$-thick layer of Pleistocene to early Pliocene diatom ooze (Unit I), $360 \mathrm{~m}$ of white nannofossil ooze, chalk, and chert of middle Eocene to Maestrichtian age was cored (Unit II). Figure 3 shows the lower part of Hole $750 \mathrm{~B}$ with the lower part of sedimentary Units III and IV and the cores drilled into the basaltic basement. Unit III consists of pale green to green gray chalk and chert. Limestones with dark bands, traces of molluscs, inoceramids and wood were recovered in the lower part at depths of 595-623 m below sea level (mbsl) (Subunit IIIC). The entire Unit III is dated as late Maestrichtian to late Turonian by foraminifers and nannoplankton, and, in part, by the dinoflagellate cysts that are described in this paper (Core 120-750B-11W).

From 623.5 to $675.5 \mathrm{mbsl}$ (Unit IV), a red brown silty claystone with coal and minor conglomerates was recovered (Fig. 2). An early to early middle Albian age for this section was determined by sporomorphs (Mohr and Gee, this volume). Below $675.5 \mathrm{mbsl}$, approximately $35 \mathrm{~m}$ basalt was drilled.

\section{MATERIAL AND METHODS}

Late Cretaceous sediments in Cores $120-748 \mathrm{C}-62 \mathrm{R}$ through $-79 \mathrm{R}$ and $120-750 \mathrm{~B}-11 \mathrm{~W}$ are composed of a broad range of glauconitic sandstones, silt, and claystones with some sandy or conglomeratic intervals. The shipboard results (Schlich, Wise, et al., 1989) determined that there were abundant carbonized wood fragments in the basal part of Hole $748 \mathrm{C}$, which are recognized by Francis and Coffin (this volume) as being of gymnospermous origin. Coarse authigenic siderite and pyrite grains and concretions were also observed. Analysis of the reddish brown, silty clay indicates that it consists primarily of kaolinite, but up to $25 \%$ siderite, $6 \%$ pyrite, and $20 \%$ altered grains can be derived from the altered basalt.

We processed 43 samples from Hole $748 \mathrm{C}$ and 1 sample from Hole $750 \mathrm{~B}$ using standard centrifuge preparation techniques for palynomorphs, in addition to straining with a $15 \mu \mathrm{m}$ mesh sieve. Smear slides using glycerine jelly were made to examine the kerogen and palynomorph content. For taxonomic determination and photographic documentation, additional single grain slides were made. ODP localities and slide numbers of the figured specimens are given in the plate captions. Coordinates are noted for sporomorphs found in smear slides, and refer to the Nikon "Microphot FX" Microscope, no. 1020-1219. The slides are deposited at the Geological Institute of the ETH (Swiss Federal Institute of Technology) in Zürich.

\section{RESULTS}

\section{Kerogen Analysis}

After using the standard processing method mentioned above, but before sieving and oxidization, the kerogen content of the samples was checked. In samples from the lower part of the investigated interval of Site 748 , the content of palynomorphs (mostly dinocysts and sporomorphs) is moderately high. The palynodebris is mostly composed of large, wellpreserved cuticle, wood, and fusinite particles, as well as bacterially degraded phytoclasts of unknown origin. Globular amorphous material and finely shredded amorphous palynodebris make up only about $10 \%-20 \%$. In samples $120-748 \mathrm{C}$ $79 \mathrm{R}-1,55-58 \mathrm{~cm}$, and $-73 \mathrm{R}-6,57-60 \mathrm{~cm}$, the amount of finely shredded amorphous material appears to be even lower. The palynofacies in these samples can be classified as the "tracheal facies" defined by Habib (1979).

In the upper part of the examined interval of Site 748 , the amount of finely shredded and amorphous material increases (up to $30 \%-50 \%$ ), so that the facies can be assigned to the xenomorphic palynofacies"' of Habib (1979).

The thermal alteration index (TAI) of the kerogen is about -2 , according to the color chart in Traverse (1988). The organic matter is thus still immature. 


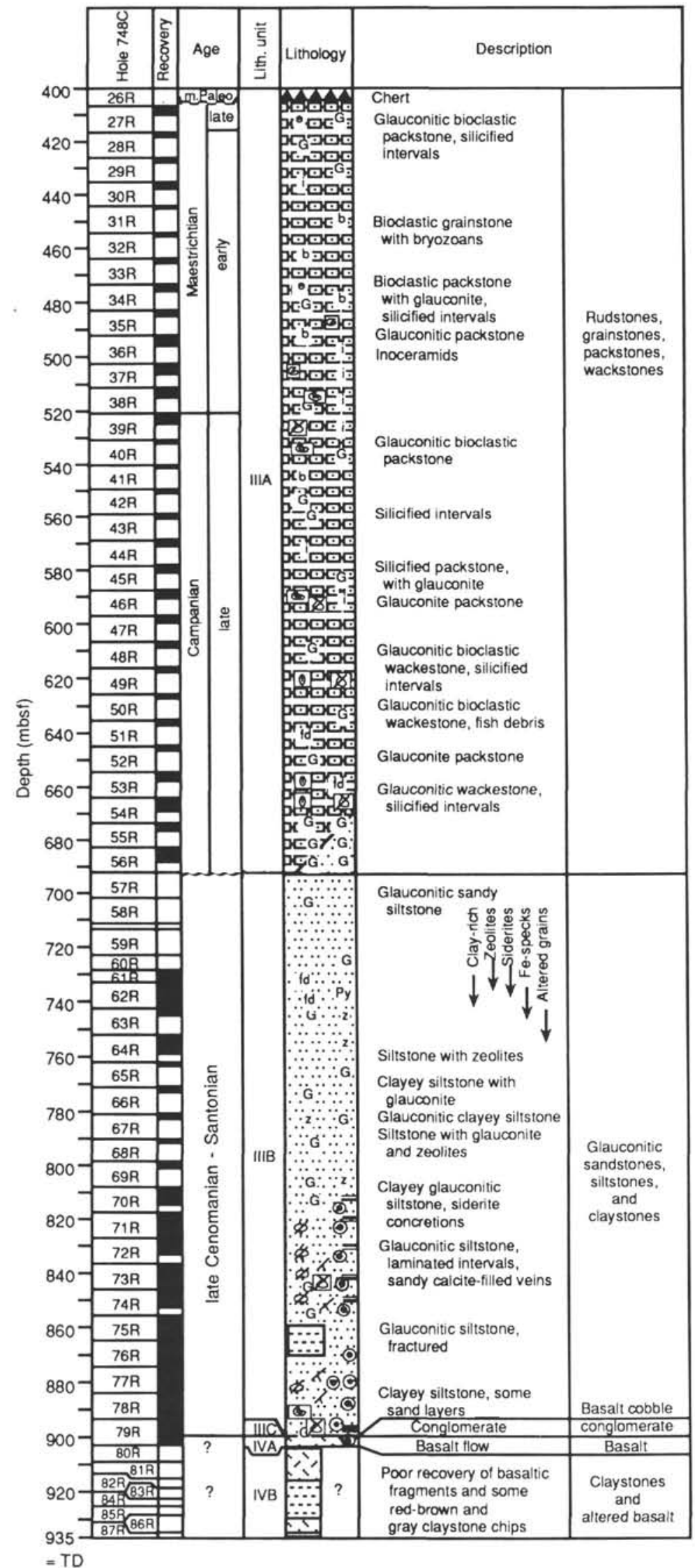

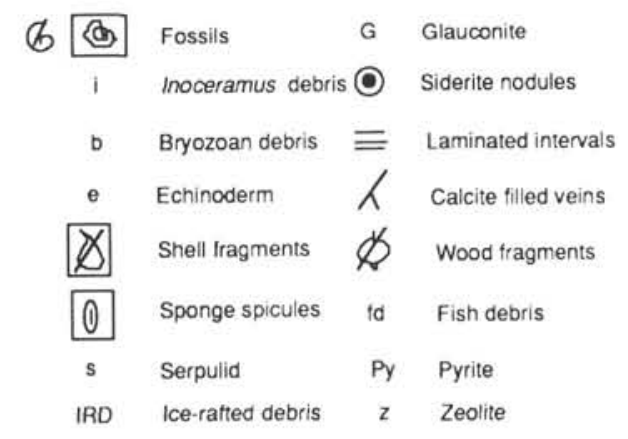

Figure 2. Detailed lithologic summary of the lower part of Site 748, western Raggatt Basin. Palynological samples, analyzed in this paper, come exclusively from lithologic Subunit IIIB. 


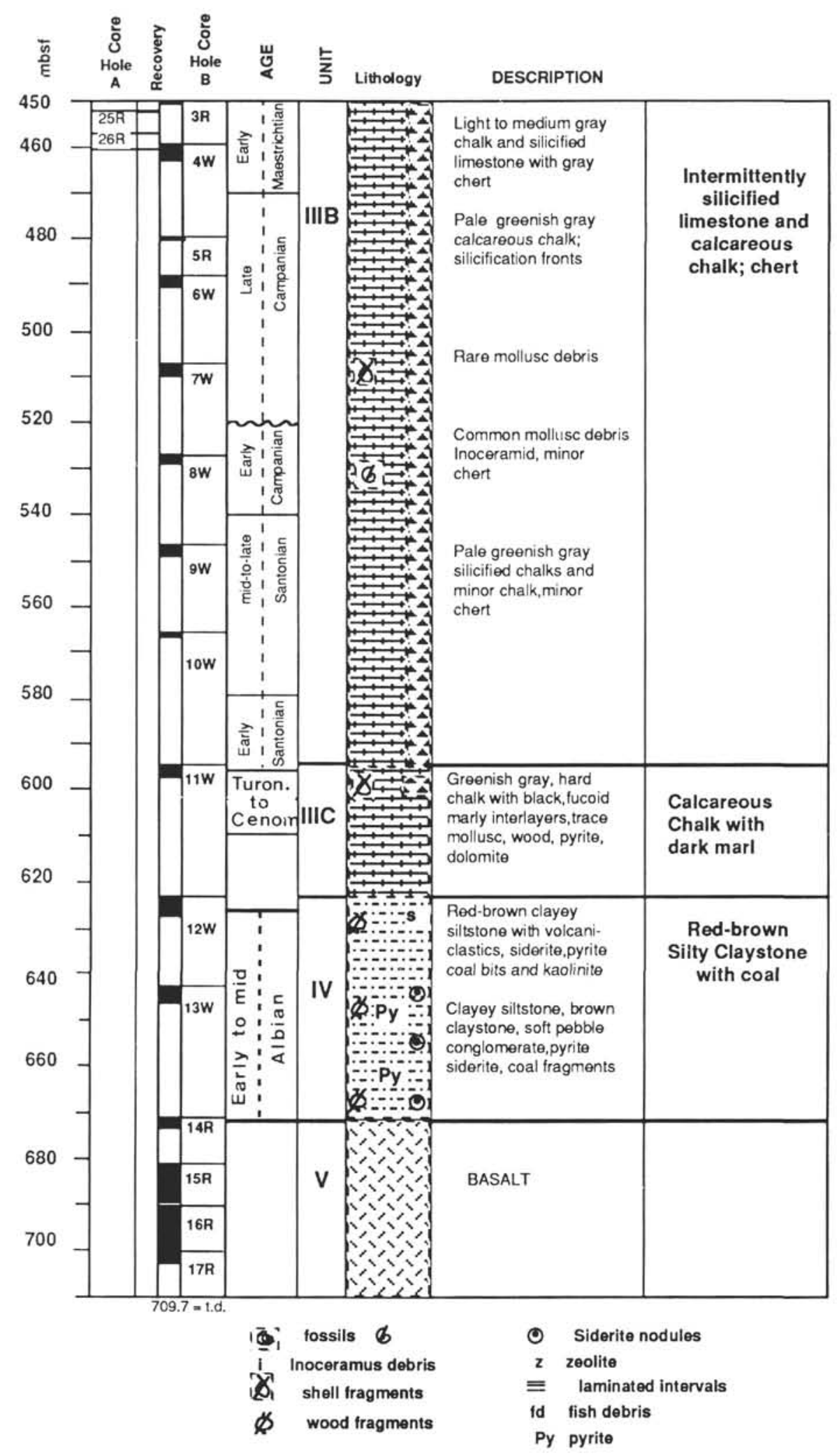

Figure 3. Lithologic summary of Site 750 . The palynological sample comes from lithologic Subunit IIIC. 
After sieving and oxidization, quantitative analysis of palynomorphs from Site 748 was conducted on those samples in which the content was high enough. On the average, 150 palynomorphs per sample were counted. Terrestrial (spores and pollen) vs. marine (dinocysts, acritarchs, and foram linings) ratios show high variability (Table 1 and Fig. 4). Low $(30 \%)$ marine percentages, however, are seen in the lower part of the section (late Cenomanian to early Turonian age; see "Biostratigraphy" section, this chapter). The marine percentages reach maxima of about $90 \%$ (Samples 120-748C-72R-1, $70-73 \mathrm{~cm}$, and $-63 \mathrm{R}-1,82-84 \mathrm{~cm}$ ). It is apparent from Figure 4 that there is a tendency toward increasing marine conditions from the bottom to the top of the section. This impression is verified by a regression line (Fig. 4). In the bottom of the hole, the regression estimates are between $40 \%$ and $50 \%$ marine, and at the top of the sequence between $70 \%$ and $80 \%$ marine. In addition to the terrestrial/marine ratio, the diversity of marine dinocyst taxa was also plotted. The highest diversity (24-25 species) is seen at the bottom of the hole (Sample 120-748C-79R-2, 138-141 cm). Other maxima are reached in the interval from Cores $120-748 \mathrm{C}-70 \mathrm{R}$ through $-65 \mathrm{R}$. A diagram (Fig. 5) in which species diversity is plotted vs. marine percentages shows highest diversity where the ratios of terrestrial input vs. marine organic matter are about balanced or are slightly shifted toward the marine side. Nutrient-rich influx from land (minerals bearing $\mathrm{P}, \mathrm{Fe}, \mathrm{Al}, \mathrm{K}$, and $\mathrm{Si}$ ) may be the reason for the high dinocyst diversity in those samples.

Table 1. Percentage of marine kerogen (dinocysts, acritarchs and foram linings) and dinocyst species diversity (number of dinocyst taxa) from selected samples of lithologic Subunit IIIB (Site 748).

\begin{tabular}{|c|c|c|c|}
\hline $\begin{array}{l}\text { Core, section, } \\
\text { interval }(\mathrm{cm})\end{array}$ & $\begin{array}{l}\text { Depth } \\
\text { (mbsf) }\end{array}$ & $\begin{array}{c}\text { Marine } \\
(\%)\end{array}$ & $\begin{array}{l}\text { Diversity } \\
\text { (species) }\end{array}$ \\
\hline \multicolumn{4}{|l|}{$120-748 \mathrm{C}$} \\
\hline $62 \mathrm{R}-4,115-117$ & 738.18 & 81 & 11 \\
\hline $62 \mathrm{R}-6,52-55$ & 740.62 & 61 & 6 \\
\hline $62 \mathrm{R}-\mathrm{CC}$ & 742.00 & 76 & 5 \\
\hline $63 \mathrm{R}-1,82-84$ & 742.82 & 91 & 8 \\
\hline 63R-CC & 751.50 & 62 & 5 \\
\hline $64 R-1,63-65$ & 752.13 & 81 & 6 \\
\hline $64 \mathrm{R}-3,78-81$ & 755.28 & 50 & 9 \\
\hline $65 \mathrm{R}-1,46-50$ & 761.46 & 70 & 11 \\
\hline $66 \mathrm{R}-1,48-51$ & 770.98 & 79 & 9 \\
\hline $67 \mathrm{R}-1,69-73$ & 780.69 & 50 & 2 \\
\hline $68 \mathrm{R}-1,30-33$ & 789.80 & 71 & 15 \\
\hline $69 \mathrm{R}-1,56-59$ & 798.03 & 62 & 6 \\
\hline $70 R-1,63-67$ & 807.63 & 69 & 15 \\
\hline $70 \mathrm{R}-4,54-57$ & 807.54 & 63 & 8 \\
\hline 70R-CC & 816.50 & 42 & 6 \\
\hline $71 \mathrm{R}-1,65-68$ & 817.15 & 68 & 4 \\
\hline $71 \mathrm{R}-6,120-123$ & 825.20 & 82 & 10 \\
\hline 71R-CC & 826.00 & 82 & 4 \\
\hline $72 \mathrm{R}-1,70-73$ & 826.70 & 87 & 9 \\
\hline 72R-CC & 835.50 & 73 & 8 \\
\hline $73 \mathrm{R}-1,57-60$ & 836.07 & 65 & 10 \\
\hline $73 R-6,60$ & 843.60 & 28 & 4 \\
\hline $74 \mathrm{R}-1,59-62$ & 845.59 & 77 & 6 \\
\hline $74 \mathrm{R}-4,56-59$ & 850.06 & 53 & 6 \\
\hline 75R-CC & 864.00 & 37 & 8 \\
\hline $76 \mathrm{R}-1,60-63$ & 865.24 & 38 & 10 \\
\hline $76 \mathrm{R}-5,120-123$ & 871.20 & 51 & 6 \\
\hline 76R-CC & 873.50 & 50 & 15 \\
\hline $77 \mathrm{R}-1,61$ & 874.11 & 46 & 3 \\
\hline 77R-CC & 883.00 & 56 & 7 \\
\hline 78R-1, 59-62 & 883.59 & 34 & 5 \\
\hline $78 R-5,105-107$ & 890.05 & 29 & 7 \\
\hline 78R-CC & 892.50 & 65 & 15 \\
\hline $79 \mathrm{R}-1,55-58$ & 893.05 & 30 & 4 \\
\hline $79 R-2,60-63$ & 894.60 & 65 & 18 \\
\hline $79 \mathrm{R}-2,136-141$ & 895.38 & 54 & 24 \\
\hline
\end{tabular}

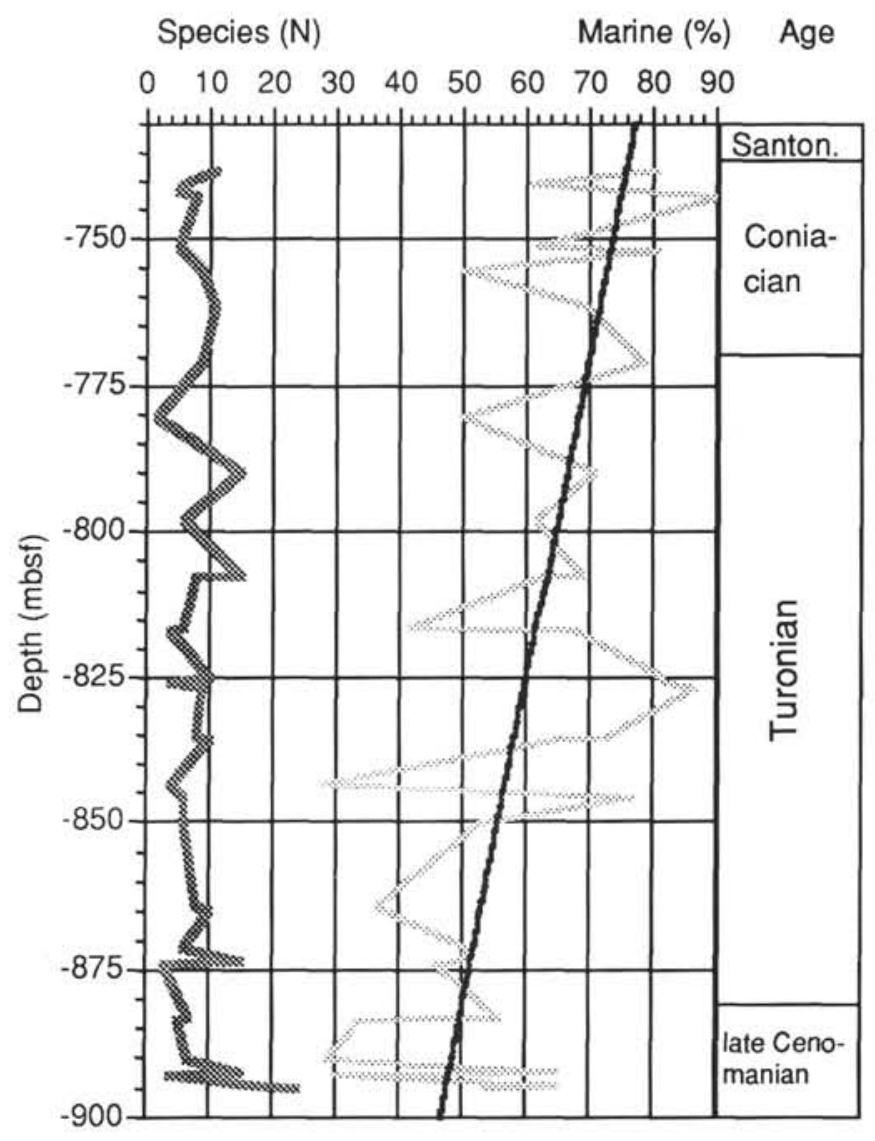

Figure 4. Dinocyst species diversity throughout lithologic Subunit IIIB (Site 748) and percentage of marine organic matter plotted vs. depth (mbsf) and age.

The organic matter of Section 120-750-11W-CC has about the same level of maturity as the kerogen of Site 748. The composition of the palynomorphs is $>90 \%$ marine (dinocysts, acritarchs) and $<10 \%$ terrestrial (sporomorphs). Most of the organic debris is finely shredded or amorphous, which is typical for "xenomorphic palynofacies" (Habib, 1978).

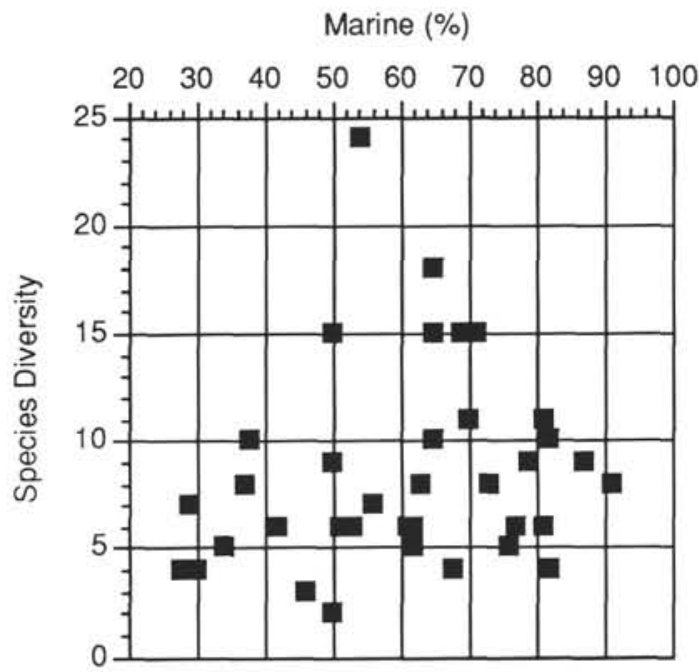

Figure 5. Scatterplot of dinocyst species diversity (number of taxa) vs. percent of marine organic matter. 


\section{THE PALYNOFLORA}

The palynoflora in Section 120-748C-62R-CC through Sample $120-748 \mathrm{C}-79 \mathrm{R}-2,138-141 \mathrm{~cm}$, as well as that in Core $120-750 \mathrm{~B}-11 \mathrm{~W}$, consists of spores, pollen, and fungal remains of terrestrial origin and marine phytoplankton, such as dinoflagellate cysts, acritarchs, and other algal cysts. Among all those palynomorphs, the dinocysts proved to be the most valuable group for stratigraphic purposes in the sedimentary sections mentioned above.

\section{Dinoflagellate Cysts}

Most of the dinocysts found in the Kerguelen Plateau material were previously described in the classic papers on Australian Mesozoic dinocysts by Deflandre and Cookson (1955) and by Cookson and Eisenack (1958, 1960, 1962, 1970, 1974). The Kerguelen Plateau dinocyst flora shares the greatest number of species with those floras of early Late Cretaceous age described by Norvick and Burger (1976) and Olivero and Palamarczuk (1987).

The dinocyst taxonomy used here generally follows the index of Lentin and Williams (1989). This index contains the full citations to the original papers used in the present paper; thus, these citations will not be repeated here in the references. A complete list of all taxa encountered in our material is given in Appendix A.

\section{TAXONOMIC REMARKS}

Tehamadinium Jan du Chêne et al., in Jan du Chêne et al., 1986 Tehamadinium sp. A

(Plate 6, Figs. 1A-B, 3, 4A-B, and 5)

These cysts contain the very prominent archeopyle of the genus Tehamadinium, consisting of two paraplates (Type $2 \mathrm{P}, 2^{\text {" }}$ and $3^{\text {" }}$; see specimens on Plate 6, Figs. 1A-B and 4A). When compared with other species of Tehamadinium, the ornamentation is very rough, consisting of thick, hollow spines that are closely arranged at the parasutures or are even fused to one another at the base. These spines are long and mostly pointed apically but are sometimes also formed conically. One apical spine is usually more prominent than others. Tehamadinium sp. A is most similar to $T$. tenuiceras (Eisenack, 1958) Jan du Chêne et al., 1986 (an Aptian form) that has spines about half of the size of Tehamadinium sp. A.

Sample size. About 12 specimens.

Measurements (6 specimens). Length about 60-70 $\mu \mathrm{m}$; width about $60-70 \mu \mathrm{m}$; length of the spines $3-8 \mu \mathrm{m}$; apical spine $10-12 \mu \mathrm{m}$.

Occurrence. Tehamadinium sp. A is found exclusively in sediments of supposedly Coniacian age (Sections 120-748C-62R-6 to -63R-1; 740.62-742.82 mbsf).

Craspedodinium Cookson and Eisenack, 1974

Craspedodinium cf. indistinctum Cookson and Eisenack, 1974

The specimens encountered in our material are similar in shape, outline, and archeopyle structure to the specimen figured by Cookson and Eisenack (1974, plate 25, fig. 7). In both cases, the archeopyle seems to be apical. The specimens in our material are, however, by far smaller (length: about $40 \mu \mathrm{m}$, width: about $35 \mu \mathrm{m}$ ) than those described by Cookson and Eisenack (1974; type specimen: $103 \times 96$ $\mu \mathrm{m})$. The age of the sediments from which the type specimen is described is thought to be Aptian-Albian.

Trithyrodinium (Drugg, 1969) Lentin and Williams, 1976

Trithyrodinium cf. sabulum Mao and Norris, 1988

(Plate 8, Figs. 2, 4, 7, and 9)

Cyst similar in appearance to Trithyrodinium sabulum Mao and Norris (1988); however, it is more pear-shaped than the specimens described by these authors (see Plate 8, Figs. 2 and 9, this paper). The apical horn is commonly less obvious than in the original description. The antapical horns are slightly more prominent and are often seen as two short protrusions, bulging out from the antapical part of the cyst.

T. sabulum occurs in the Tarim Basin (China) in the Kukebai to Yigeziya formations, which are correlated with the Cenomanian to the post-Coniacian (?Maestrichtian).

\section{Terrestrial Palynomorphs from Hole 748C}

The terrestrial palynoflora consists of fungal remains, moss and fern spores, one megaspore, and conifer and angiosperm pollen. Of these, fern spores are the most common. The most frequently encountered spore is, by far, Cyathidites minor, which is present in almost all samples in the section, even in those that are highly marine in composition. Another fairly common spore is Laevigatosporites ovatus. The other, more distinctive moss and fern spores play only a minor role in the flora. The few fungal remains found are shield-shaped fruitbodies lacking central stalks and ostioles.

Bisaccate and trisaccate pollen grains are scarce in these microfloras, which is in direct contrast to their numbers in the microflora recovered from slightly older early Albian sediments in the region (Mohr and Gee, this volume). The few grains encountered are also usually so badly preserved that it is difficult to assign them to species. Their poor preservation may be caused in part by the use of strong oxidizing agents in the preparation of the samples. The air bladders of saccate pollen, which are often found to contain balls of pyrite at nearby localities, may be more susceptible to damage than other pollen if the oxidation process that destroys the pyrite balls also affects the delicate bladders that house them.

Angiosperm pollen is more frequently found in the higher parts of the sequence. The most common pollen is the monocolpate Clavatipollenites hughesii, although the pollen of several other tricolpate and tricolporate genera also occur.

Taxonomic determinations were predominantly based on the papers by Backhouse (1988), Burger $(1975,1980)$, Cookson (1947), Couper $(1953,1960)$, Dettmann $(1963,1973,1986$ a, 1986b), Dettmann and Thomson (1987), and Filatoff (1975). A complete list of all taxa is given in Appendix B.

\section{Biostratigraphy}

\section{Dinocysts, Hole $748 \mathrm{C}$}

The ranges of the dinoflagellate cysts in this material are mostly compiled from the work of Williams and Bujak (1985), Helby et al. (1987), and McMinn (1988). These three papers form the basis for Figure 6. In comparison to other Cenomanian/Turonian palynofloras from the Australian area (Norvick and Burger, 1976), the floras in our material contain 0-25 species (average: 8 ) and are generally low in diversity (Fig. 4). This makes age determination more difficult.

The most common dinocyst in Cores $120-748 \mathrm{C}-79 \mathrm{R}$ and $-78 \mathrm{R}$ is Cribroperidinium edwardsii, which, according to Helby et al. (1987), has an acme in the late Diconodinium multispinum Interval Zone and early Palaeohystrichophora infusoriodes Interval Zone. Other common cysts are Diconodinium multispinum, the name-giving cyst of the D. multispinum Zone (Helby et al., 1987), and Palaeohystrichophora infusorioides, the name-giving cyst of the overlying $P$. infusorioides Zone. These zones range, respectively, from the early Cenomanian to the early late Cenomanian and from the latest Cenomanian to the mid to late Turonian. The base of the $P$. infusorioides Zone is defined by the last occurrence of Pseudoceratium ludbrookiae.

Thus, in regard to the occurrence of the three most common dinocyst species, the deepest cores of Hole $748 \mathrm{C}$ $(120-748 \mathrm{C}-79 \mathrm{R}$ and $-78 \mathrm{R})$ can be placed in the time interval between the upper part of the $D$. multispinum Zone and the lower part of the $P$. infusorioides Zone of Helby et al. (1987). This defines the age of the sediment as late Cenomanian to early Turonian. Unfortunately, the marker form $P$. lud brookiae, which would give evidence of a Cenomanian age, is absent. There are, however, dinocyst taxa, found in the lower 


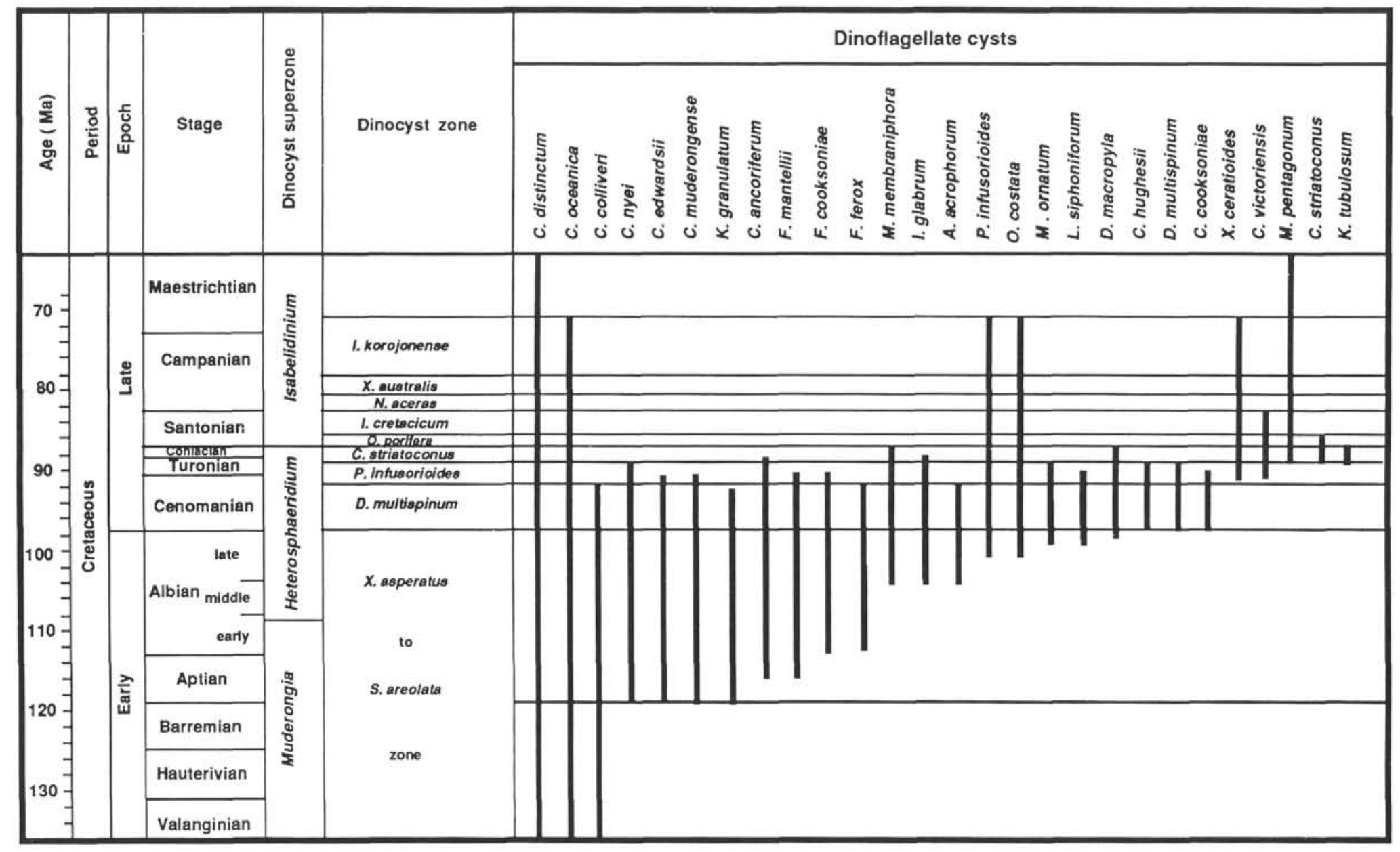

Figure 6. Stratigraphic ranges of selected dinoflagellate cysts found in lithologic Subunits IIIB (Site 748) and IIIC (Site 750), according to the literature. Time scale according to Helby et al. (1987). 
part of the section, which are confined only to the Cenomanian, according to the existing literature. Litosphaeridium siphoniphorum glabrum is considered by Lucas-Clark (1984) to be a subspecies restricted to the Cenomanian, although Litosphaeridium siphoniphorum siphoniphorum also occurs in the Turonian. In our material, L. siphoniphorum glabrum was encountered only in samples of Cores 120-748C-79R and -76R.

The occurrence of Ascodinium acrophorum was previously reported by Cookson and Eisenack (1960) from the Albian and Cenomanian of the Freemantle area (Australia). At Hole 748C A. acrophorum is restricted to Core $120-748 \mathrm{C}-79 \mathrm{R}$. The last appearance of ?Kallosphaeridium granulatum was previously reported at the end of the Cenomanian (Fig. 6). In our material, this species is found at the base of the section (120-748C-79R-2 through -79R-1, see Table 2). Valensiella griphus, described by Norvick and Burger (1976) from Cenomanian sediments, was also encountered exclusively in Core 120-748C-79R.

In the material described here, the first (poorly preserved) specimen of the genus Chatangiella (C. victoriensis) was observed in Section 120-748C-76R-1. From Sample 120-748C$70 \mathrm{R}-1,63-67 \mathrm{~cm}$, upward, this cyst starts to be more common (see Table 2). According to the literature (McMinn, 1988), C. victoriensis appears for the first time in the mid-Isabelidinium acuminatum Zone, which is about equivalent to the upper Palaeohystrichophora infusorioides Zone of Helby et al. (1987). The mid-Isabelidinium acuminatum Zone and the upper Palaeohystrichophora infusorioides Zone are thought to correspond to the mid-Turonian.

Beginning with Sample 120-748C-65R-1, 46-50 cm, and continuing through Sample 120-748C-62R-4, 115-117 cm, Kleithriasphaeridium tubulosum was regularly observed. According to Helby et al. (1987), $K$. tubulosum was found exclusively in the Conosphaeridium striatoconus Zone, which is of Coniacian age. C. striatoconus itself was only observed in Samples 120-748C-64R-1, 63-65 cm, and -62R-4, 115-117 $\mathrm{cm}$.

Isabelidinium sp. was found in Sample 120-748C-66R-1, $48-51 \mathrm{~cm}$, through Section 120-748C-61R-CC. In this inter$\mathrm{val}$, Xenascus cf. ceratioides, a more or less nonspiny form of this genus, also appears. Xenascus was found by Mao and Mohr (this volume) consistently until Core $120-748 \mathrm{C}-32 \mathrm{R}$, which is equivalent in time to the early Maestrichtian. According to Yun (1981), nonspiny specimens of the genus Xenascus seem to occur mostly from the "Senonian" on (Coniacian through Maestrichtian). He describes similar unornamented forms under the name $X$. esbeckiana.

The change from a Coniacian to a probable Santonian flora occurs between Samples 120-748C-62R-4, 115-117 cm, and $62 \mathrm{R}-1,52-59 \mathrm{~cm}$, where the compositional differences between the floras can be observed (last appearance of $C$. striatoconus and $K$. tubulosum and the frequent occurrence of $X$. cf. ceratioides). A detailed description and interpretation of the Santonian to Maestrichtian dinocyst floras in Sample 120-748C-62R-2 through Section 120-748C-27R-2 are the subject of the paper by Mao and Mohr (this volume).

Summarizing the marine plankton results, the ranges of the dinocysts suggest ages between the late Cenomanian through Coniacian/early Santonian. The age of the lower part of the section (Samples 120-748C-79R-2, 138-141 cm through $-79 \mathrm{R}-1,55-58 \mathrm{~cm}$ ), and possibly also Core 120-748C-78R (see sporomorph evidence below), is most likely late Cenomanian. Core 120-748C-77R through Section 120-748C-73R-CC seem to be of early Turonian age. The mid-Turonian was reached in Sample $120-748$ C-73R-6, 57-60 cm. A Coniacian age is probable for the section from Samples 120-748C-66R-1, 48-51 cm, through 120-748C-62R-4, 115-117 cm. Probable Santonian sediments are preserved between Sample 120-748C-62R-1, $52-59 \mathrm{~cm}$, and Section 120-748C-61R-CC.

Turning to the sporomorph evidence, most of the spores and pollen species found throughout the section (Table 3) have fairly long ranges in the Late Jurassic and Cretaceous. There are, however, a few sporomorphs that have restricted ranges in the southern Gondwana area. Although taxa characteristic of major spore-pollen zones (e.g., those listed by Helby et al., 1987) do not occur in the material, a few biostratigraphically indicative sporomorphs were found. These species, listed with their stratigraphic ranges in Figure 7, contribute to the dating of the core sediments. Figure 7, as well as the species ranges discussed in the following analysis, unless otherwise cited, is based exclusively on the spore-pollen zonation established by Helby et al. (1987), one of the few that cover the Cenomanian through Santonian interval in southern Gondwana.

In southern Gondwana, Dictyotosporites complex makes its last, if irregular, appearance at the end of the Cenomanian. Its only occurrence in the section in Sample 120-748C-78R-1, $59-62 \mathrm{~cm}$, indicates an age no younger than the Cenomanian for the lowermost part of the section. Nyssapollenites lanosus also occurs once in the section in Section 120-748C-76R-CC. In late Albian to Turonian sequences from southern Australia, this pollen species ranges from the mid-Cenomanian to the Turonian (Dettmann, 1973) and thus indicates that this part of the section can be no younger than the mid-Cenomanian. Another biostratigraphically significant spore, Interulobites intraverrucatus, was also found in the lower part of the section, from Sections 120-748C-79R-2 through 120-748C76R-5. This species has a restricted range in the Late Cretaceous, ranging from the latest Albian to the Coniacian, and supports an early Late Cretaceous age for the lower part of the section.

Contignisporites fornicatus occurs sporadically throughout the section. Its last appearance in the literature in the early Santonian limits the upper part of the section to an age no younger than the early Santonian. A slightly younger Coniacian age is indicated for the upper part of the section by Clavatipollenites hughesii, which occurs frequently until the late Cenomanian and only irregularly until its last appearance in the early Santonian. Thus, the occurrence of $C$. hughesii in the uppermost part of the section limits the upper age boundary to the basal Santonian, although its frequency in the uppermost samples most likely indicates an age older than the Santonian.

In summary, the ranges of selected pollen and spores found in Hole $748 \mathrm{C}$ support the dinocyst evidence for an early Late Cretaceous age, bracketing this age to an interval between the mid-Cenomanian to the Coniacian or possibly early Santonian.

\section{Dinocysts, Hole $750 B$}

Only one sample (Section 120-750B-11W-CC) was examined. The range overlap of certain taxa found in this sample, such as Palaeohystrichophora infusorioides (first appearance datum $[\mathrm{FAD}]=$ Vraconian), Disphaeria macropyla $(\mathrm{FAD}=$ Vraconian; last appearance datum $[\mathrm{LAD}]=$ Coniacian), and Canninginopsis colliveri ( $\mathrm{LAD}=$ mid-Cenomanian) make an early to middle Cenomanian age for this sample most likely.

Members of the genus Isabelidinium were also encountered. Because the specimens greatly differ in shape and size, it is difficult to assign this form to a particular species. Some of the specimens could be assigned to I. glabrum, which is regularly found during the Cenomanian. Other specimens may 
Table 2. Stratigraphic occurrences of the dinoflagellate cysts in lithologic Subunit IIIB (Site 748).

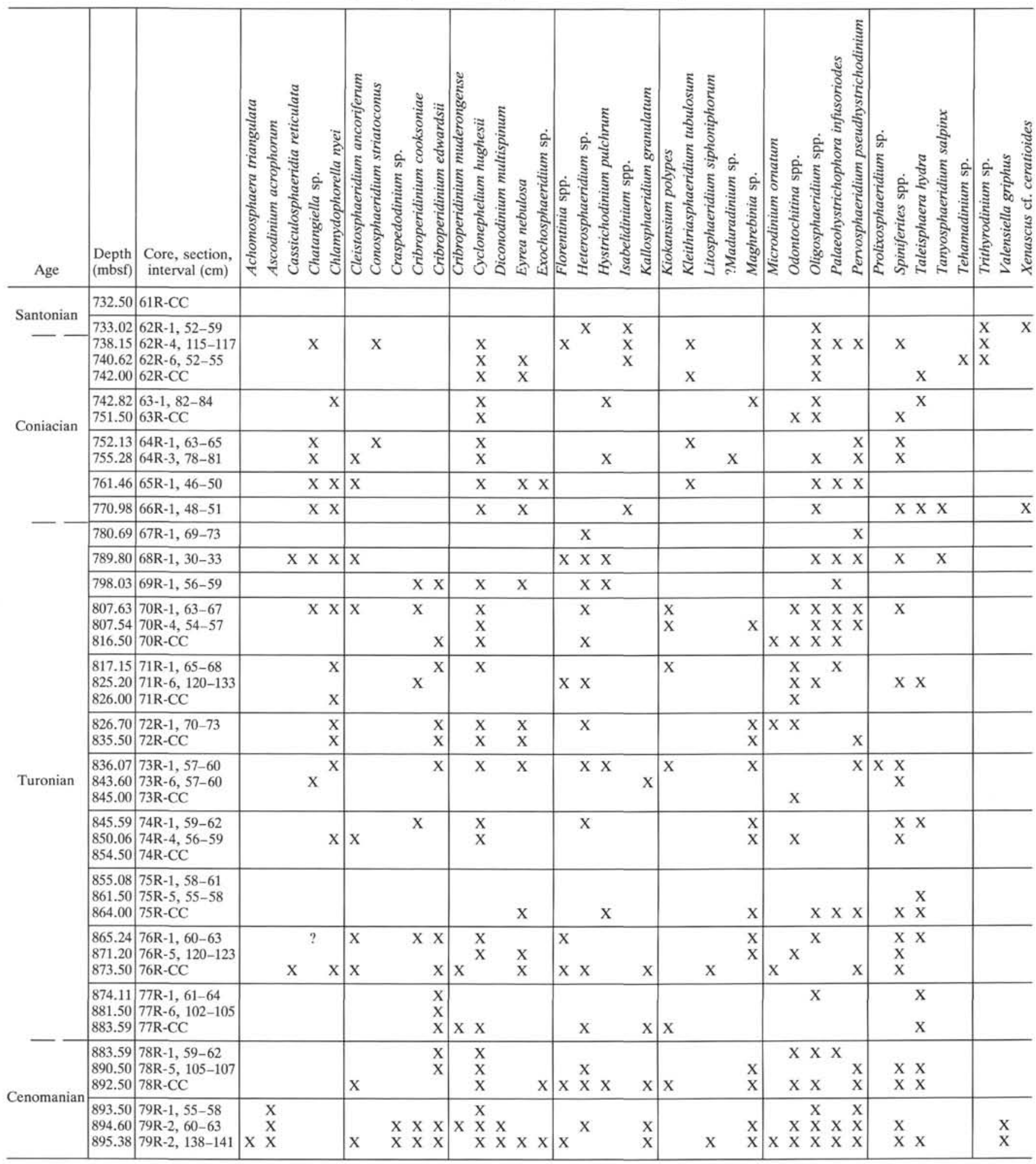

belong to $I$. belfastense or even to the genus Chatangiella. This would imply that sediments of younger age (Turonian to Coniacian) higher up in the core were washed down as a result of the special coring technique mentioned by Mohr and Gee (this volume). If so, this dinocyst assemblage can then be interpreted as a mixture of floras from the ?early to midCenomanian and the Turonian/Coniacian.

\section{PALEOCEANOGRAPHIC IMPLICATIONS}

During the (early to mid) Albian, after the formation of the volcanic basement (Whitechurch et al., this volume), large parts of the Kerguelen Plateau must have still been terrestrial, as there is no evidence of marine fossils in sediments of this age (Mohr and Gee, this volume). 
Table 3. Stratigraphic distribution of the pollen and spores in lithologic Subunit IIIB (Site 748).

\begin{tabular}{|c|c|c|c|c|c|c|c|c|c|c|c|c|c|c|c|c|c|c|c|c|c|c|c|c|c|c|c|c|c|}
\hline $\begin{array}{l}\text { Depth } \\
\text { (mbsf) }\end{array}$ & $\begin{array}{l}\text { Core, section, } \\
\text { interval }(\mathrm{cm})\end{array}$ & 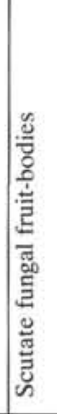 & 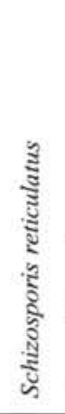 & 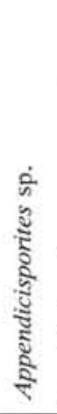 & 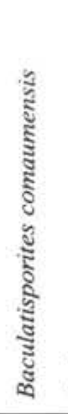 & 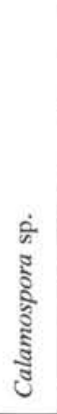 & 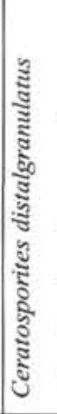 & 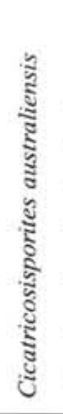 & 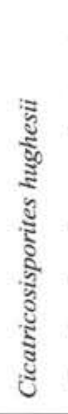 & 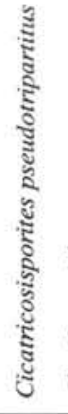 & 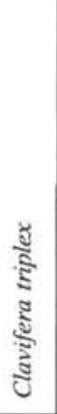 & 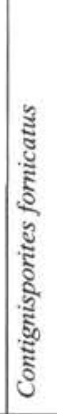 & 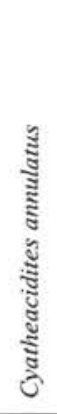 & 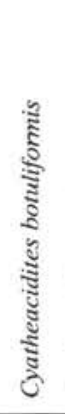 & 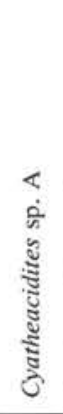 & 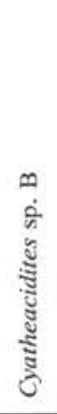 & 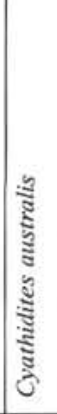 & 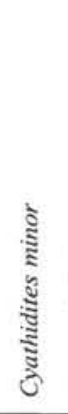 & 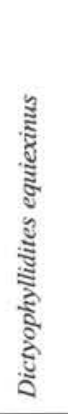 & 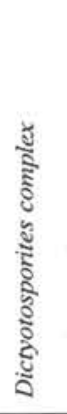 & 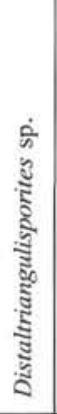 & 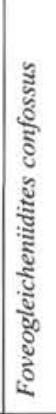 & 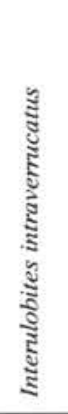 & 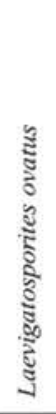 & 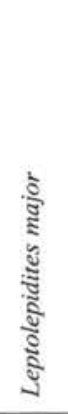 & 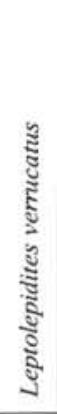 & 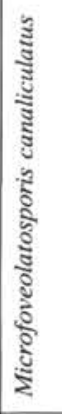 & 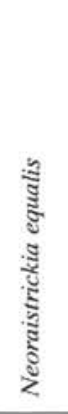 & 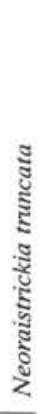 \\
\hline 732.50 & 61R-CC & & & & & & & & & & & & & & & & & & & & & & & & & & & & \\
\hline $\begin{array}{l}733.02 \\
738.15 \\
740.62 \\
742.00\end{array}$ & $\begin{array}{l}62 \mathrm{R}-1,52-59 \\
62 \mathrm{R}-4,115-117 \\
62 \mathrm{R}-6,52-55 \\
62 \mathrm{R}-\mathrm{CC}\end{array}$ & $\mathrm{X}$ & & & $\mathrm{x}$ & $\mathrm{x}$ & & $\mathrm{X}$ & & & $\begin{array}{l}X \\
X\end{array}$ & $\mathrm{X}$ & $\mathrm{x}$ & & & & $x$ & $\begin{array}{l}X \\
X\end{array}$ & & & & & & $\begin{array}{l}X \\
X \\
x\end{array}$ & & $\begin{array}{l}\mathrm{X} \\
\mathrm{X}\end{array}$ & $\mathrm{X}$ & & \\
\hline $\begin{array}{l}742.82 \\
751.50\end{array}$ & $\begin{array}{l}63-1,82-84 \\
63 R-C C\end{array}$ & $x$ & & & & & & & & & $\mathrm{X}$ & & $\begin{array}{l}X \\
X\end{array}$ & & & & & $\mathrm{X}$ & & & & & & $\mathrm{x}$ & & & & & \\
\hline $\begin{array}{l}752.13 \\
755.28 \\
\end{array}$ & $\begin{array}{l}64 \mathrm{R}-1,63-65 \\
64 \mathrm{R}-3,78-81 \\
\end{array}$ & & & & & & & & & & $\mathrm{X}$ & & & & & & & $\begin{array}{l}X \\
X\end{array}$ & & & & & & $\mathrm{X}$ & & & & $\mathrm{X}$ & \\
\hline 761.46 & $65 \mathrm{R}-1,46-50$ & & & & & & & & & & & & & & & & & $\mathrm{X}$ & & & & & & $\mathrm{X}$ & & & & & \\
\hline 770.98 & $66 \mathrm{R}-1,48-51$ & & & & & & & & & & & & & & & & & $\mathrm{X}$ & & & & & & & & & & & \\
\hline 780.69 & $67 \mathrm{R}-1,69-73$ & & & & & & & & & & & & & & & & & $\mathrm{X}$ & & & & & & & & & & & \\
\hline 789.80 & $68 \mathrm{R}-1,30-33$ & $\mathrm{X}$ & & & & & & & & & & & & & & & & $\mathrm{X}$ & & & & & & $\mathrm{X}$ & & & & & \\
\hline 798.03 & $69 \mathrm{R}-1,56-59$ & & & & & & & & & & $\mathrm{X}$ & & & & & & & $\mathrm{X}$ & & & & & & & & & & & \\
\hline $\begin{array}{l}807.63 \\
807.54 \\
816.50\end{array}$ & $\begin{array}{l}70 \mathrm{R}-1,63-67 \\
70 \mathrm{R}-4,54-57 \\
70 \mathrm{R}-\mathrm{CC}\end{array}$ & & & & & & & & & & & $x$ & & & & & & $\begin{array}{l}\mathrm{X} \\
\mathrm{X} \\
\mathrm{x}\end{array}$ & & & & & & & & & & & \\
\hline $\begin{array}{l}817.15 \\
825.20 \\
826.00 \\
\end{array}$ & $\begin{array}{l}\text { 71R-1, } 65-88 \\
\text { 71R-6, 120-133 } \\
\text { 71R-CC }\end{array}$ & & & & & & & & & & & & & & & & & $\begin{array}{l}X \\
X\end{array}$ & & & & & & $\mathrm{X}$ & & & & $\mathrm{x}$ & \\
\hline $\begin{array}{l}826.70 \\
835.50 \\
\end{array}$ & $\begin{array}{l}72 \mathrm{R}-1,70-73 \\
72 \mathrm{R}-\mathrm{CC}\end{array}$ & & & & & & & & & & & & & & & & & $\begin{array}{l}\mathrm{X} \\
\mathrm{x}\end{array}$ & & & & & & & & & & & \\
\hline $\begin{array}{l}836.07 \\
843.60 \\
845.00 \\
\end{array}$ & $\begin{array}{l}73 \mathrm{R}-1,57-60 \\
73 \mathrm{R}-6,57-60 \\
73 \mathrm{R}-\mathrm{CC}\end{array}$ & & & & & & & & & & & & & & & & & $\mathrm{x}$ & & & & & & & & & $\mathrm{X}$ & & \\
\hline $\begin{array}{l}845.59 \\
850.06 \\
854.50 \\
\end{array}$ & $\begin{array}{l}74 \mathrm{R}-1,59-62 \\
74 \mathrm{R}-4,56-59 \\
74 \mathrm{R}-\mathrm{CC}\end{array}$ & & & & & & & & & & & & & & & & & $\begin{array}{l}X \\
X\end{array}$ & & & & & & & & & & & \\
\hline $\begin{array}{l}855.08 \\
861.50 \\
864.00\end{array}$ & $\begin{array}{l}75 \mathrm{R}-1,58-61 \\
75 \mathrm{R}-5,55-58 \\
75 \mathrm{R}-\mathrm{CC}\end{array}$ & & & & & & $\mathrm{X}$ & & & & & & & & & & $\begin{array}{l}X \\
X\end{array}$ & $\mathrm{x}$ & & & & & & $\mathrm{X}$ & & & $\mathrm{X}$ & & \\
\hline $\begin{array}{l}865.24 \\
871.20 \\
873.50 \\
\end{array}$ & $\begin{array}{l}76 \mathrm{R}-1,60-63 \\
76 \mathrm{R}-5,120-123 \\
76 \mathrm{R}-\mathrm{CC}\end{array}$ & $\mathrm{X}$ & & $\mathrm{X}$ & & & $\mathrm{X}$ & $\begin{array}{l}x \\
x\end{array}$ & $\mathrm{x}$ & $\mathrm{X}$ & & $\mathrm{x}$ & $\mathrm{x}$ & $\mathrm{x}$ & $\mathrm{x}$ & $\mathrm{X}$ & $\begin{array}{l}x \\
x\end{array}$ & $\begin{array}{l}\mathrm{X} \\
\mathrm{x} \\
\end{array}$ & & & $\mathrm{x}$ & $\begin{array}{l}\mathrm{x} \\
\mathrm{x}\end{array}$ & $\mathrm{x}$ & $\begin{array}{l}x \\
x\end{array}$ & & & & $\mathrm{x}$ & \\
\hline $\begin{array}{l}874.11 \\
881.50 \\
883.59 \\
\end{array}$ & $\begin{array}{l}77 \mathrm{R}-1,61-64 \\
77 \mathrm{R}-6,102-105 \\
77 \mathrm{R}-\mathrm{CC}\end{array}$ & & & & & & $\begin{array}{l}x \\
x \\
\end{array}$ & $\mathrm{X}$ & & & & & & & & & & $\begin{array}{l}x \\
x\end{array}$ & $\mathrm{X}$ & & & $\mathrm{x}$ & & $\mathrm{X}$ & & & & & \\
\hline $\begin{array}{l}883.59 \\
890.50 \\
892.50\end{array}$ & $\begin{array}{l}\text { 78R-1, 59-62 } \\
\text { 78R-5, 105-107 } \\
\text { 78R-CC }\end{array}$ & & & & & & & $\begin{array}{l}X \\
X\end{array}$ & & $\mathrm{X}$ & & $\begin{array}{l}\mathrm{X} \\
\mathrm{X}\end{array}$ & $\mathrm{x}$ & $\mathrm{X}$ & $\mathrm{x}$ & & $\mathrm{X}$ & $\begin{array}{l}\mathrm{X} \\
\mathrm{X} \\
\mathrm{X}\end{array}$ & $\mathrm{X}$ & & $\mathrm{x}$ & $\begin{array}{l}\mathrm{x} \\
\mathrm{x}\end{array}$ & $\mathrm{x}$ & $\begin{array}{l}X \\
X \\
X\end{array}$ & & & $\begin{array}{l}\mathrm{X} \\
\mathrm{X}\end{array}$ & $\mathrm{X}$ & \\
\hline $\begin{array}{l}893.50 \\
894.60 \\
895.38\end{array}$ & $\begin{array}{l}79 \mathrm{R}-1,55-58 \\
79 \mathrm{R}-2,60-63 \\
79 \mathrm{R}-2,138-141\end{array}$ & $\begin{array}{l}x \\
x\end{array}$ & $\begin{array}{l}X \\
X\end{array}$ & $X$ & & $x$ & $x$ & $x$ & & $x$ & & $\mathrm{x}$ & $x$ & $\mathrm{x}$ & $x$ & & & $\begin{array}{l}X \\
X \\
X\end{array}$ & & & $x$ & $\begin{array}{l}\mathrm{X} \\
\mathrm{X} \\
\mathrm{X}\end{array}$ & $x$ & $\begin{array}{l}\mathrm{X} \\
\mathrm{X} \\
\mathrm{X}\end{array}$ & $\mathrm{x}$ & & $\begin{array}{l}x \\
x\end{array}$ & $\mathrm{x}$ & $x$ \\
\hline
\end{tabular}

Major flooding of the Kerguelen Plateau area must have occurred between the early to mid-Albian and between the early to mid-Cenomanian, which may be preserved at Site 750. Even if the early to mid-Cenomanian is not found at Site 750 (see "Biostratigraphy" section, this chapter), there is evidence from Eltanin Core E54-7 $\left(55^{\circ} 52.78^{\prime} \mathrm{S}, 81^{\circ} 07.09^{\prime} \mathrm{E}\right)$ that marine sediments were accumulated during the (late) Cenomanian (Quilty, 1973).
The fossil record seems to be discontinuous and resumes with late Cenomanian deposits at the base of Hole $748 \mathrm{C}$. There, the kerogen is more terrestrial influenced than in the middle Cenomanian. If we consider the overall kerogen trends in the investigated interval of Site 748 (Fig. 4), the abundance of terrestrial material decreases from the upper Cenomanian through the Coniacian deposits, with maxima in the lower Turonian. 
Table 3 (continued).

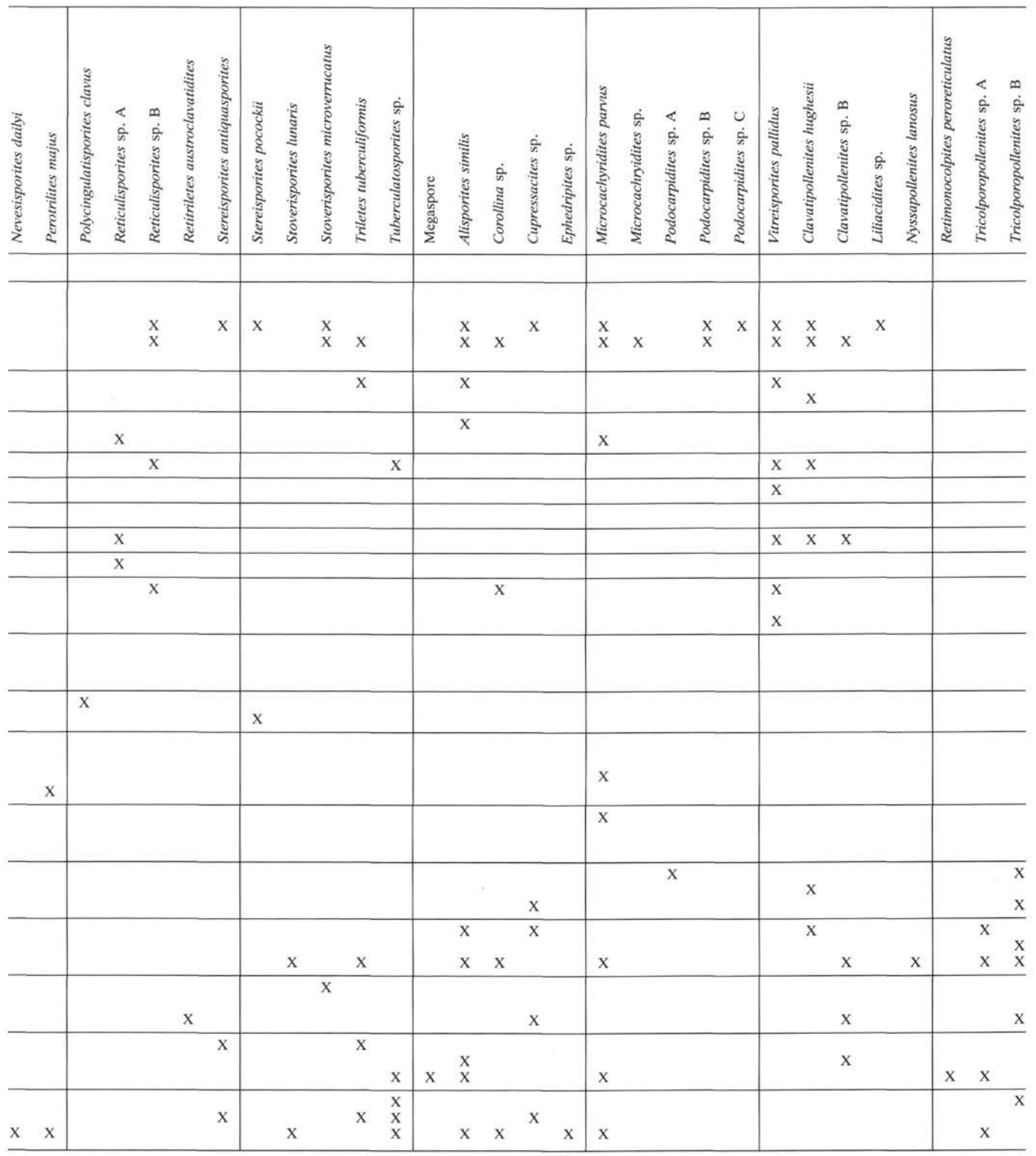

During the late Cenomanian (Cores 120-748C-79R and $-78 \mathrm{R})$, the terrestrial kerogen source must have been still fairly close to the sedimentary basin, because the terrestrial particles (wood, cuticles) are coarse in comparison with the organic matter in the younger part of this section. In the late Cenomanian interval, the number of dinoflagellate species (species diversity) is the largest (24-25 species).
The late Cenomanian is considered by many authors (Ernst et al., 1983; Haq et al., 1987; Hilbrecht, 1989) to be a time of worldwide regression (in comparison with the mid-Cenomanian and early Turonian). Increased terrestrial input in the sediments of presumed late Cenomanian age can therefore be correlated with this regression, when greater land areas were exposed. The high dinocyst diversity in these layers can be 


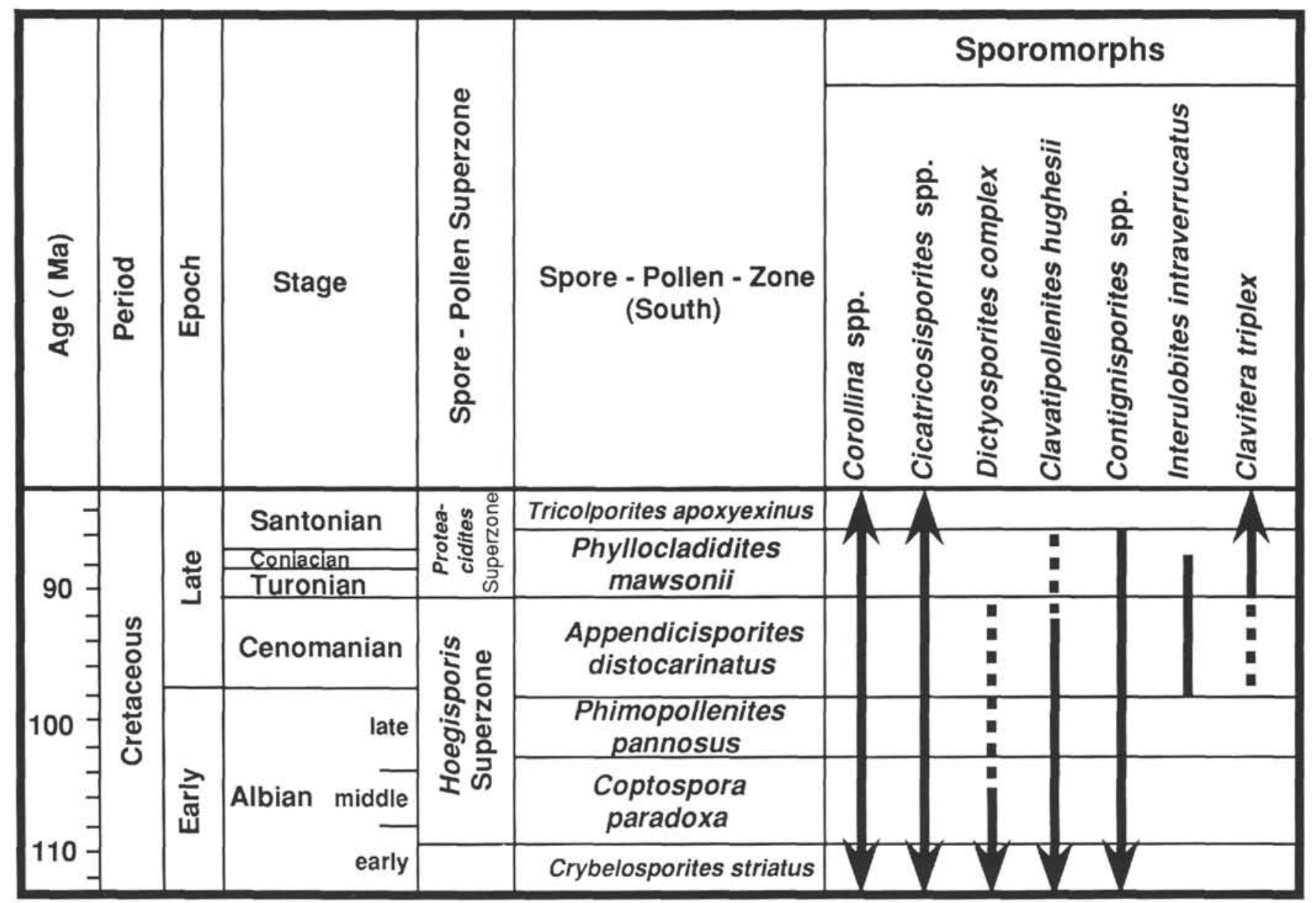

Figure 7. Stratigraphic ranges of selected pollen and spores found in lithologic Subunit IIIB (Site 748). Time scale, zonation scheme, and species ranges after Helby et al. (1987).

explained by the increased nutrients entering the inner to outer shelf areas where the largest numbers of cyst producing species generally occur. This pattern is strongly overprinted by surface currents (Harland, 1983), where large dinocyst concentrations are associated with areas of convergence and/or divergence.

From the Turonian time on, terrestrial input generally decreased. However, in the early Turonian deposits, maxima of terrestrial input were noted and may correlate to short regressive intervals. During late Turonian and Coniacian/early Santonian times, conditions became increasingly more openmarine, a tendency found during the Campanian and Maestrichtian (Mao and Mohr, this volume).

Sedimentation rates calculated using the ages of the different sections of lithologic Subunit IIIB (Fig. 2) of Site 748 seem to be low for a shelf environment. If we take a Turonian age for the sediment between 780.69 and 883.59 mbsf, during this time interval, $102.90 \mathrm{~m}$ of sediment would have accumulated. If we assume a total length of about $2.5 \mathrm{~m}$.y. for the Turonian, sediment accumulated at a rate of $41.2 \mathrm{~m} / \mathrm{m} . \mathrm{y}$. For the Coniacian (duration ca. 1 m.y.), sediments for which seem to be more or less completely preserved $(39.83 \mathrm{~m})$, a sedimentation rate of about $39.8 \mathrm{~m} / \mathrm{m} . \mathrm{y}$. was calculated. These low sedimentation rates of $3-5 \mathrm{~cm} / 1000 \mathrm{yr}$ seem to fit with observations of extensive bioturbation in the glauconitic siltstones of lithologic Subunit IIIB at Site 748 (Schlich, Wise, et al., 1989). Low sedimentation rates are characteristic of glauconites deposited in normal saline waters from 20 to $730 \mathrm{~m}$ in depth (Pettijohn, 1975).

\section{CONCLUSIONS}

Based on dinocyst and sporomorph evidence, the sediments investigated are (late) Cenomanian to Coniacian/ Santonian in age. Kerogen analysis, especially ratios of terrestrial vs. marine organic matter, indicate a high terrestrial input in the late Cenomanian. During the Turonian and Coniacian/early Santonian, the sequence became increasingly more marine. Low sedimentation rates of about 3-5 $\mathrm{cm} / 1000 \mathrm{yr}$ were calculated for lithologic Subunit IIIB of Site 748.

\section{ACKNOWLEDGMENTS}

We wish to express our warmest thanks to S. W. Wise, Jr. (Tallahassee), who initiated this study by providing us with the material that forms the basis of this work. Dr. D. Lazarus (Zürich) provided help with the figures and read the manuscript critically. Dr. H. Hilbrecht (Zürich) was helpful in discussing paleoceanographic questions. Dr. D. Hos (Cottesloe, Australia) kindly sent additional processed samples and slides that helped to clarify the age of some of the cores. We also thank A. Leeman (Zürich) for the processing of samples and U. Gerber (Zürich) for the photographic work. This study was supported by the Swiss National Fund, Grant No. 20.5402.87. 


\section{REFERENCES}

Backhouse, J., 1988. Late Jurassic and Early Cretaceous palynology of the Perth Basin, Western Australia. Bull. Geol. Surv. West. Aust., 135:1-233.

Burger, D., 1975. Cenomanian spores and pollen grains from Bathurst Island, Northern Territory, Australia. Bull. Bur. Miner. Resour. Aust., 151:14-167.

1980. Palynological studies in the Lower Cretaceous of the Surat Basin, Australia. Bull. Bur. Miner. Resour. Aust., 189:1106.

Coffin, M. F., Munschy, M., Colwell, J. B., Schlich, R., Davies, H. L., and Li, Z.-G., 1990. Seismic stratigraphy of the Raggatt Basin, Southern Kerguelen Plateau: tectonic and paleoceanographic implications. Geol. Soc. Am. Bull., 102:563-579.

Colwell, J. B., Coffin, M. F., Pigram, C. J., Davies, H. L., Stagg, H.M.J., and Hill, P. J., 1988. Seismic stratigraphy and evolution of the Raggatt Basin, southern Kerguelen Plateau. Mar. Pet. Geol., 5:75-81.

Cookson, I. C., 1946. Pollen analysis of lignite from the Kerguelen Archipelago. Nature, 157:658.

1947. Plant microfossils from the lignites of Kerguelen Archipelago. Brit. Aust. N.Z. Antarc. Res. Exped. 1929-1931 Repts., Ser. A, 127-142.

Cookson, I. C., and Eisenack, A., 1958. Microplankton from Australian and New Guinea upper Mesozoic sediments. Proc. R. Soc. Victoria, 70:95-128.

1960. Microplankton from Australian Cretaceous sediments. Micropaleontology, 6:1-18.

1962. Additional microplankton from Australian Cretaceous sediments. Micropaleontology, 8:485-507.

1970. Cretaceous microplankton from the Eucla Basin, Western Australia. Proc. R. Soc. Victoria, 83:137-157.

1974. Mikroplankton aus australischen mesozoischen und tertiären Sedimenten. Palaeontographica B, 148:44-93.

Couper, R. A., 1953. Upper Mesozoic and Cainozoic spores and pollen grains from New Zealand. Bull. N.Z. Geol. Surv. Palaeontol., 22:1-77.

1960. New Zealand Mesozoic and Cainozoic plant microfossils. Bull. N.Z. Geol. Surv. Palaeontol., 32:1-87.

Deflandre, G., and Cookson, I. C., 1955. Fossil microplankton from Australian late Mesozoic and Tertiary sediments. Aust. J. Mar. Freshwater Res., 6:242-313.

Dettmann, M. E., 1963. Upper Mesozoic microfloras from southeastern Australia. Proc. R. Soc. Victoria, 77:1-148.

1973. Angiospermous pollen from Albian to Turonian sediments of eastern Australia. Spec. Publ. Geol. Soc. Aust., $4: 3-34$.

1986a. Early Cretaceous palynoflora of subsurface strata correlative with the Koonwarra Fossil Bed, Victoria. Mem. Assoc. Australas. Palaeontol., 3:79-110.

1986b. Significance of the Cretaceous-Tertiary spore genus Cyatheacidites in tracing the origin and migration of Lophosoria (Filicopsida). Spec. Pap. Palaeontol., 35:63-94.

Dettmann, M. E., and Thomson, M.R.A., 1987. Cretaceous palynomorphs from the James Ross Island area, Antarctica-a pilot study. Bull. Br. Antarct. Surv., 77:13-59.

Ernst, G., Schmid, F., and Seibertz, E., 1983. Event-Stratigraphie im Cenoman und Turon von Nordwest-Deutschland. Zitteliana, $10: 531-554$

Filatoff, J., 1975. Jurassic palynology of the Perth Basin, Western Australia. Palaeontographica B, 154:1-113.

Habib, D., 1979. Sedimentary origin of North Atlantic Cretaceous palynofacies. In Talwani, M., Hay, W., and Ryan, W.B.F. (Eds.), Deep Drilling Results in the Atlantic Ocean: Continental Margins and Paleoenvironment. Am. Geophys. Union, Maurice Ewing Ser., 3:420-437.

Haq, B. u., Hardenbol, J., and Vail, P. R., 1987. Chronology of fluctuating sea levels since the Triassic. Science, 235:1156-1167.

Harland, R., 1983. Distribution maps of recent dinoflagellate cysts in bottom sediments from the North Atlantic Ocean and adjacent seas. Palaeontology, 26:321-387.

Harris, W. K., 1976. Palynology of cores from Deep Sea Drilling Sites 327, 328, and 330, South Atlantic Ocean. In Barker, P., Dalziel,
I.W.D., et al., Init. Repts. DSDP, 36: Washington (U.S. Govt. Printing Office), 761-815.

Helby, R., Morgan, R., and Partridge, A. D., 1987. A palynological zonation of the Australian Mesozoic. In Jell, P. A. (Ed.), Studies in Australian Mesozoic Palynology. Mem. Assoc. Australas. Palaeontol., 4:1-94.

Hilbrecht, H., 1989. Redeposition of Late Cretaceous pelagic sediments controlled by sea-level fluctuations. Geology, 17:10721075.

Holdgate, M. W., 1960. The Royal Society Expedition to southern Chile. Proc. R. Soc. London B, 152:434-441.

Houtz, R. E., Hayes, D. E., and Markl, R. G., 1977. Kerguelen Plateau bathymetry, sediment distribution, and crustal structure. Mar. Geol., 25:95-130.

Jan du Chêne, R., et al., 1986. Guide pratique pour la détermination de kystes de Dinoflagellés fossiles: le complexe Gonyaulacysta. Bull. Cent. Rech. Explor.-Prod. Elf-Aquitaine, 12:1-479.

Kent, D. V., and Gradstein, F. M., 1985. A Cretaceous and Jurassic geochronology. Geol. Soc. Am. Bull., 96:1419-1427.

LeClaire, L., Bassias, Y., Denis-Clochiatti, M., Davies, H. L., Gautier, I., Gensous, B., Giannesini, P.-J., Morand, F., Patriat, P., Ségoufin, J., Tesson, M., and Wannesson, J., 1987. Lower Cretaceous basalt and sediments from the Kerguelen Plateau. Geo-Mar. Lett., 7:169-176.

Lentin, J. K., and Williams, G. L., 1989. Fossil dinoflagellates: index to genera and species. Am. Assoc. Stratigr. Palynol. Contrib. Ser., 20:1-473.

Lucas-Clark, J., 1984. Morphology of species of Litosphaeridium (Cretaceous, dinophyceae). Palynology, 8:165-193.

Mao, S.-Z., and Norris, G., 1988. Late Cretaceous-early Tertiary dinoflagellates and acritarchs from the Kashi Area, Tarim Basin, Xinjiang Province, China. Roy. Ontario Mus., Life Sciences Contrib., 150:1-93.

McMinn, A., 1988. Outline of a Late Cretaceous dinoflagellate zonation of northwestern Australia. Alcheringa, 12:137-156.

Norvick, M. S., and Burger, D., 1976. Palynology of the Cenomanian of Bathurst Island, Northern Territory, Australia. Bull. Bur. Miner. Resour. Geol. Geophys., 151:1-169.

Olivero, E. B., and Palamarczuk, S., 1987. Amonites y dinoflagelados cenomanianos de la Isla James Ross, Antartida. Ameghiniana, 24:35-49.

Pettijohn, E. J., 1975. Sedimentary Rocks: New York (Harper and Row).

Quilty, P. G., 1973. Cenomanian-Turonian and Neogene sediments from the Northeast of Kerguelen Ridge, Indian Ocean. J. Geol. Soc. Aust., 20:361-368.

Schlich, R., Wise, S. W., Jr., et al., 1989. Proc. ODP, Init. Repts., 120: College Station, TX (Ocean Drilling Program).

Traverse, A., 1988. Paleopalynology: Boston (Unwin Hyman).

Uwins, P.J.R., and Batten, D. J., 1988. Early to mid-Cretaceous palynology of northeast Libya. In El-Arnauti, A., et al. (Eds.), Subsurface Palynostratigraphy of Northeast Libya: 215-257.

Williams, G. L., and Bujak, J. P., 1985. Mesozoic and Cenozoic dinoflagellates. In Bolli, H., Saunders, J. B., and Perch-Nielsen, K. (Eds.), Plankton Stratigraphy: Cambridge (Cambridge Univ. Press), 847-964.

Yun, H.-S., 1981. Dinoflagellaten aus der Oberkreide (Santon) von Westfalen. Palaeontographica B, 177:1-89.

Date of initial receipt: 8 May 1990

Date of acceptance: 24 November 1990

Ms 120B-196

\section{APPENDIX A}

\section{List of Dinoflagellate Cysts and Acritarchs}

Dinoglagellate Cysts from Hole 748C

Achomosphaera triangulata (Gerlach, 1961) Davey and Williams, 1969; Plate 1, Fig. 1

Ascodinium acrophorum (Cookson and Eisenack, 1960a) Helenes, 1983; Plate 1, Fig. 5

Batiacasphaera sp.; Plate 8, Fig. 5

Cassiculosphaeridia reticulata Davey, 1969a; Plate 1, Figs. 6A-B 
Chatangiella tripartita (Cookson and Eisenack, 1960) Lentin and Williams, 1976; Plate 1, Figs. 2-4

Chatangiella victoriensis (Cookson and Manum, 1964) Lentin and Williams, 1976; Plate 1, Figs. 7A-B

Chatangiella sp.

Chlamydophorella nyei Cookson and Eisenack, 1958; Plate 1, Fig. 9

Circulodinium distinctum (Deflandre and Cookson, 1955) Jansonius, 1986; Plate 2, Figs. 7A-B

Cleistosphaeridium ancoriferum (Cookson and Eisenack, 1960) Davey et al., 1966, emend. Cookson and Eisenack, 1968; Plate 1, Fig. 8

Cleistosphaeridium sp.

Conosphaeridium striatoconus (Deflandre and Cookson, 1955) Cookson and Eisenack, 1969; Plate 1, Figs. 10A-B

Coronifera oceanica (Cookson and Eisenack, 1958) Mao and Norris, 1988; Plate 2, Fig. 6

Craspedodinium cf. indistinctum Cookson and Eisenack, 1974; Plate 3, Figs. 1A-B

Cribroperidinium cooksoniae Norvick, 1976; Plate 3, Figs. 4 and 6

Cribroperidinium edwardsii (Cookson and Eisenack, 1958) Davey, 1969; Plate 2, Fig. 4

Cribroperidinium muderongense (Cookson and Eisenack, 1958) Davey, 1969; Plate 2, Figs. 1A-B

Cyclonephelium hughesii Clarke and Verdier, 1967

Cyclonephelium sp.; Plate 3, Fig. 2

Diconodinium multispinum (Deflandre and Cookson, 1955) Morgan 1977; Plate 2, Fig. 5

Diconodinium psilatum Morgan, 1977; Plate 8, Fig. 1

Diconodinium sp.

Disphaeria macropyla (Cookson and Eisenack, 1960a) Norvick, 1973

Exochosphaeridium muelleri Yun, 1981; Plate 3, Figs. 7A-B

Eyrea nebulosa Cookson and Eisenack, 1958; Plate 2, Fig. 2

Florentinia ferax (Deflandre, 1973b) Duxbury, 1980; Plate 3, Figs. $3 \mathrm{~A}-\mathrm{B}$

Florentinia mantellii (Davey and Williams, 1966) Davey and Verdier, 1973; P. 3, Fig. 5

Florentinia cooksoniae (Ch. Singh, 1971) Duxbury, 1980

Heterosphaeridium heterocanthum (Deflandre and Cookson, 1955) Eisenack and Kjellström, 1971a

Hystrichodinium pulchrum Deflandre, 1935; Plate 4, Fig. 5

?Kallosphaeridium granulatum (Norvick, 1976) Stover and Evitt, 1978; Plate 5, Fig. 1

Isabelidinium belfastense (Cookson and Eisenack, 1961a) Lentin and Williams, 1977a; Plate 4, Fig. 3

Kiokansium polypes (Cookson and Eisenack, 1962) Below, 1982; Plate 4, Fig. 2

Kleithriasphaeridium tubulosum (Cookson and Eisenack, 1969) Stover and Evitt, 1978; Plate 4, Figs. 8A-B

Kleithriasphaeridium sp.; Plate 8, Fig. 8

Litosphaeridium siphoniphorum (Cookson and Eisenack, 1958) Davey and Williams, 1966, subsp. glabrum Lucas-Clark, 1984

?Maduradinium sp.; Plate 4, Fig. 4

Maghrebinia membraniphora (Cookson and Eisenack, 1962b) Below, 1981a; Plate 4, Figs. 1 and 7

Microdinium ormatum Cookson and Eisenack, 1960

Microdinium setosum Sarjeant, 1966b; Plate 4, Fig. 6

Odontochitina costata Alberta, 1961

Odontochitina operculata (O. Wetzel, 1933) Deflandre and Cookson, 1955

Oligosphaeridium astigerum (Gocht, 1959) Davey and Williams, 1969; Plate 5, Fig. 3

Oligosphaeridium complex (White, 1842) Davey and Williams, 1966

Ovoidinium diversum Davey, 1979b; Plate 5, Figs. 6A-B

Palaeohystrichophora infusoriodes Deflandre, 1935; Plate 6, Figs. 2A-B

Palaeopteridinium cretaceum (Pocock, 1962) Davey, 1970

Pervosphaeridium pseudhystrichodinium (Deflandre, 1937) Yun, 1981; Plate 5, Figs. 2A-B

Prolixosphaeridium conulum Davey, 1969a; Plate 5, Fig. 5

Sentusidinium sp.; Plate 8, Fig. 6

Spiniferites ramosus (Ehrenberg, 1838) Loeblich and Loeblich, 1966

Spiniferites wetzelii (Deflandre, 1937b) Sarjeant, 1970; Plate 5, Figs. $6 \mathrm{~A}-\mathrm{B}$

Surculosphaeridium sp.

Taleisphaera hydra Duxbury, 1979a; Plate 5, Fig. 7
Tehamadinium sp. A; Plate 6, Figs. 1A-B, 3, 4A-B, and 5

Trichodinium castanea (Deflandre, 1935) Clarke and Verdier, 1967

Trithyrodinium cf. sabulum Mao and Norris, 1988; Plate 8, Figs. 2, 4, 7 , and 9

Valensiella griphus Norvick, 1976; Plate 6, Fig. 6

Xenascus cf. ceratioides (Deflandre, 1937b) Lentin and Williams, 1973; Plate 8, Fig. 3

\section{Acritarchs from Hole 748C}

Micrhystridium spp.

Pterospermella australiensis

Veryhachium reductum

Veryhachium singulare

\section{Dinoflagellate Cysts from Hole 750B}

Batiacasphaera sp.; Plate 7, Fig. 5

Canninginopsis colliveri (Cookson and Eisenack, 1960b) Backhouse, 1988; Plate 7, Fig. 1

Cleistosphaeridium sp.; Plate 7, Fig. 8

Cometodinium comatum Srivastava, 1984; Plate 7, Fig. 7

Disphaeria macropyla Cookson and Eisenack, 1960a) Norvick, 1976; Plate 7, Fig. 3

Litosphaeridium siphoniphorum (Cookson and Eisenack, 1958) Davey and Williams, 1966; subsp. glabrum Lucas-Clark, 1984; Plate 7, Fig. 9

Hystrichodinium pulchrum Deflandre, 1935

Impagidinium sp.

Isabelidinium sp.

Microdinium ornatum Cookson and Eisenack, 1960; Plate 5, Fig. 8

Odontochitina costata Alberti, 1961

Odontochitina operculata (O. Wetzel, 1933) Deflandre and Cookson, 1955; Plate 7, Fig. 2

Oligosphaeridium complex (White, 1842) Davey and Williams, 1966

Palaeohystrichophora infusorioides Deflandre, 1935

Psaligonyaulax deflandrei (Sarjeant, 1966b) Sarjeant, 1982b; Plate 7, Fig. 4

Pterodinium cingulatum granulatum (Clarke and Verdier, 1967) Lentin and Williams, 1981; Plate 7, Fig. 6

Spiniferites sp.

Tanyosphaeridium salpinx Norvick, 1976; Plate 7, Fig. 10

\section{APPENDIX B}

Terrestrial Palynomorphs from Hole 748C

\section{Fungal and Nondinoflagellate Algal Remains}

Scutate fungal fruit-body (ascotroma) lacking ostiole (several types) Schizosporis reticulatus Cookson and Dettmann, 1959 emend. Pierce, 1961

\section{Cryptogamic Spores}

Appendicisporites sp., cf. A. jansonii Pocock, 1962; Plate 9, Fig. 1

Baculatisporites comaumensis (Cookson, 1953) Potonié, 1956; Plate 9, Fig. 2

Calamospora sp.; Plate 9, Fig. 3

Ceratosporites distalgranulatus Couper, 1958) Kemp, 1970; Plate 9, Fig. 4

Cicatricosisporites australiensis (Cookson, 1953) Potonié, 1956; Plate 9, Fig. 5

Cicatricosisporites hughesii Dettmann 1963; Plate 9, Fig. 6

Cicatricosisporites pseudotripartitus (Bolchovitina, 1961) Dettmann, 1963

Clavifera triplex (Bolchovitina, 1953) Bolchovitina, 1966; Plate 9, Fig. 7

Contignisporites fornicatus Dettmann, 1963; Plate 9, Fig. 8

Cyatheacidites annulatus Cookson, 1947 ex Potonié, 1956; Plate 9, Fig. 9

Cyatheacidites botuliformis Dettmann, 1986b; Plate 9, Fig. 10

Cyatheacidites $\mathrm{sp}$. A; Plate 9, Fig. 11

Cyatheacidites sp. B

Cyathidites australis Couper, 1953; Plate 9, Fig. 12

Cyathidites minor Couper, 1953; Plate 9, Fig. 13

Dictyophyllidites equiexinus (Couper, 1958) Dettmann, 1963; Plate 10, Fig. 1 
Dictyotosporites complex Cookson and Dettmann, 1958; Plate 10, Fig. 2 Distaltriangulisporites sp.; Plate 10, Fig. 3

Foveogleicheniidites confossus (Hedlund, 1966) Burger, 1975; Plate 10 , Fig. 4

Interulobites intraverrucatus (Brenner, 1963) Phillips and Felix, 1972; Plate 10, Fig. 5

Laevigatosporites ovatus Wilson and Webster, 1946; Plate 10, Fig. 6 Leptolepidites major Couper 1958; Plate 10, Fig. 7

Leptolepidites verrucatus Couper 1953; Plate 10, Fig. 8

Microfoveolatosporis canaliculatus Dettmann, 1963; Plate 10, Fig. 9

Neoraistrickia equalis (Cookson and Dettmann, 1958) Backhouse, 1988; Plate 10, Fig. 10

Neoraistrickia truncata (Cookson, 1953) Potonié, 1956; Plate 10, Fig. 11

Nevesisporites dailyi (Cookson and Dettmann, 1958) Burger, 1987

Perotrilites majus (Cookson and Dettmann, 1958) Evans, 1970; Plate 10, Fig. 12

Polycingulatisporites clavus (Balme, 1957) Burger, 1980; Plate 10, Figs. 13 and 14

Reticulisporites (sensu Uwin and Batten, 1988, pl. 67, figs. 1 and 2) sp. A; Plate 10, Fig. 15

Reticulisporites (sensu Uwin and Batten, 1988, pl. 67, figs. 1 and 2) sp. B; Plate 10, Fig. 16

Retitriletes austroclavatidites (Cookson, 1953) Döring et al. in Krutzsch, 1963; Plate 10, Fig. 17

Stereisporites antiquasporites (Wilson and Webster, 1946) Dettmann, 1963

Stereisporites pocockii Burger 1980; Plate 11, Fig. 1

Stoverisporites lunaris (Cookson and Dettmann, 1958) Burger, 1975
Stoverisporites microverrucatus Burger, 1975; Plate 11; Fig. 2

Triletes tuberculiformis Cookson, 1947; Plate 11, Fig. 3

Tuberculatosporites sp.; Plate 11, Fig. 4

Megaspore; Plate 11, Fig. 5

\section{Gymnospermous Pollen}

Alisporites similis (Balme, 1957) Dettmann, 1963; Plate 11, Fig. 6 Corollina (Classopollis) sp.; Plate 11, Fig. 7

Cupressacites sp.; Plate 11, Fig. 8

Ephedripites sp.; Plate 11, Fig. 9

Microcachryidites parvus Couper, 1960; Plate 11, Figs. 10 and 11

Microcachryidites sp. (bisaccate and trisaccate forms); Plate 11, Fig. 12

Podocarpidites sp. A; Plate 11, Fig. 13

Podocarpidites sp. B; Plate 11, Fig. 14

Podocarpidites sp. C

Vitreisporites pallidus (Reissinger, 1950) Nilsson, 1958; Plate 11, Fig. 15

\section{Angiospermous Pollen}

Clavatipollenites hughesii Couper, 1958; Plate 11, Fig. 16

Clavatipollenites sp. 8 (sensu Dettmann, 1973, pl. 2, Figs 8-10); Plate 11, Fig. 17

Liliacidites sp.; Plate 11, Figs. 18 and 19

Nyssapollenites lanosus Dettmann, 1973; Plate 11, Fig. 20

Retimonocolpites peroreticulatus (Brenner, 1963) Doyle, 1975; Plate 11, Fig. 21

Tricolporopollenites sp. A; Plate 11, Fig. 22

Tricolporopollenites sp. B; Plate 11, Fig. 23 


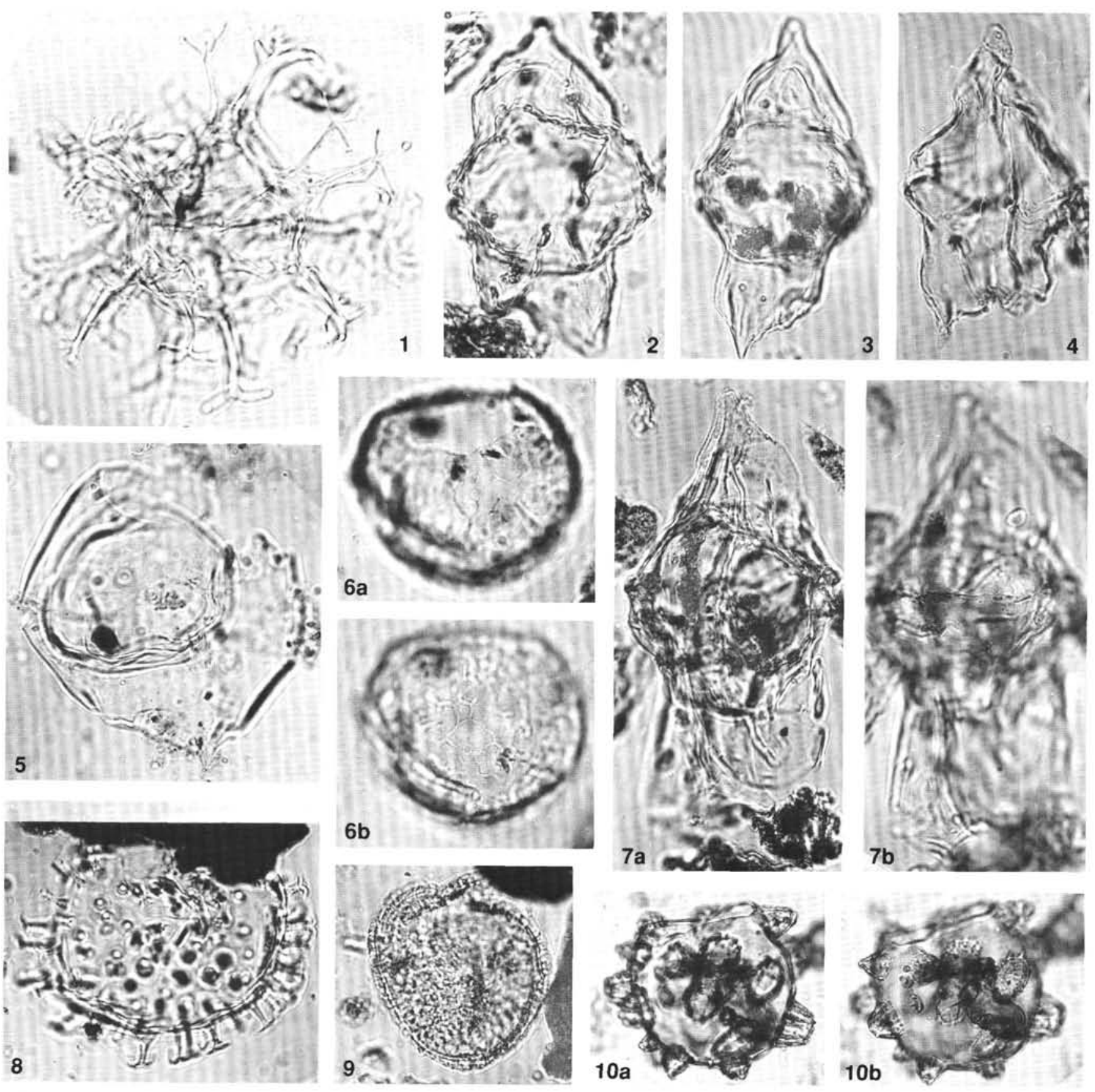

Plate 1. All magnifications at $\times 1000$, unless otherwise noted. 1. Achomosphaera triangulata. Sample $120-748 \mathrm{C}-79 \mathrm{R}-2,138-141 \mathrm{~cm} ; \mathrm{sl}$. S4, $31.2 / 94.5$. 2. Chatangiella tripartita. Sample $120-748 \mathrm{C}-62 \mathrm{R}-4,115-117 \mathrm{~cm}$; sl. S1, 33.8/97. 3. Chatangiella tripartita. Sample $120-748 \mathrm{C}-$ $65 \mathrm{R}-1,46-50 \mathrm{~cm} ; \mathrm{sl}$. S2, 41.2/92.2. 4. Chatangiella tripartita. Sample $120-748 \mathrm{C}-65 \mathrm{R}-1,46-50 \mathrm{~cm} ; \mathrm{sl}$. S2, 34/91. 5. Ascondinium acrophorum. Sample 120-748C-79R-2, 138-141 cm; sl. S2, 43.9/100.2. 6. Cassiculosphaeridia reticulata. Sample 120-748C-76R-CC; sl. S1, 43/91.5. 7. Chatangiella victoriensis. Sample 120-748C-68R-1,30-33 cm; sl. S3, 37.1/98. 8. Cleistosphaeridium ancoriferum. Sample 120-748C-78RCC; sl. S1, 42.7/97.8. 9. Clamydophorella nyei. Sample 120-748C-79R-2, 138-141 cm; sl. S1, 32.2/89.8. 10. Conosphaeridium striatoconus. Sample $120-748 \mathrm{C}-62 \mathrm{R}-4,115-117 \mathrm{~cm}$; sl. S3, 40.2/88.2; $\times 500$. 

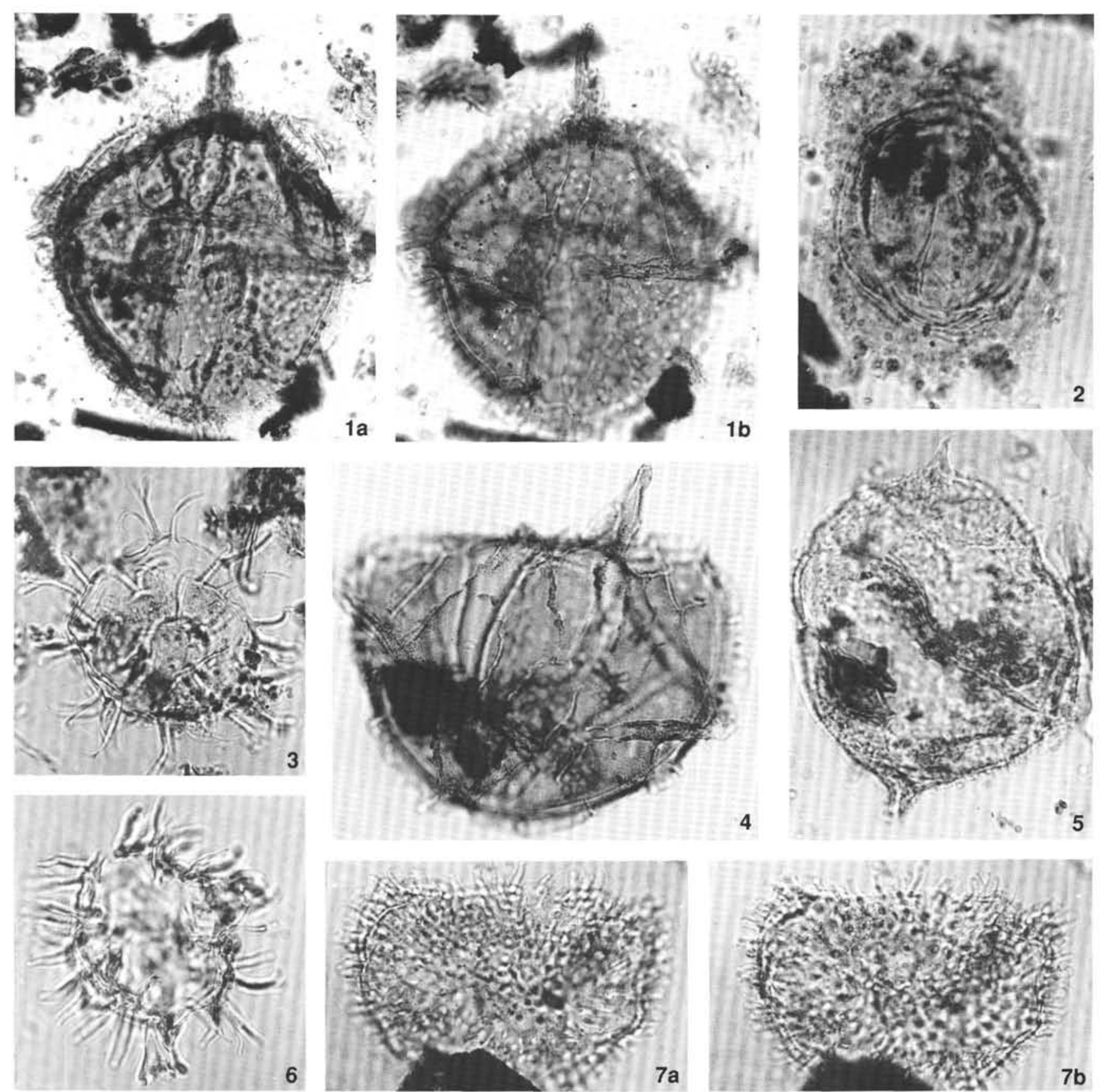

Plate 2. All magnifications at $\times 1000$, unless otherwise noted. 1. Cribroperidinium muderongense. Sample 120-748C-79R-2, 60-63 cm; sl. S1, 40.3/93.2. 2. Eyrea nebulosa. Sample 120-748C-79R-2, 138-141 cm; sl. S2, 46.2/98.5. 3. Cleistosphaeridium sp. Sample 120-748C-63R-CC, 13-16 cm; sl. S2, 42.2/87.8. 4. Cribroperidinium edwardsii. Sample 120-748C-79R-2, 138-141 cm; sl, 6; $\times 500$. 5. Diconodinium multispinum. Sample 120-748C-79R-2, 138-141 cm; sl. S4, 51.2/91.2. 6. Coronifera oceanica. Sample 120-748C-68R-1, 30-33 cm; sl. S3, 40.5/94.2. 7. Circulodinium distinctum. Sample 120-748C-71R-1, 65-68 cm; sl. S1, 46.2/88. 

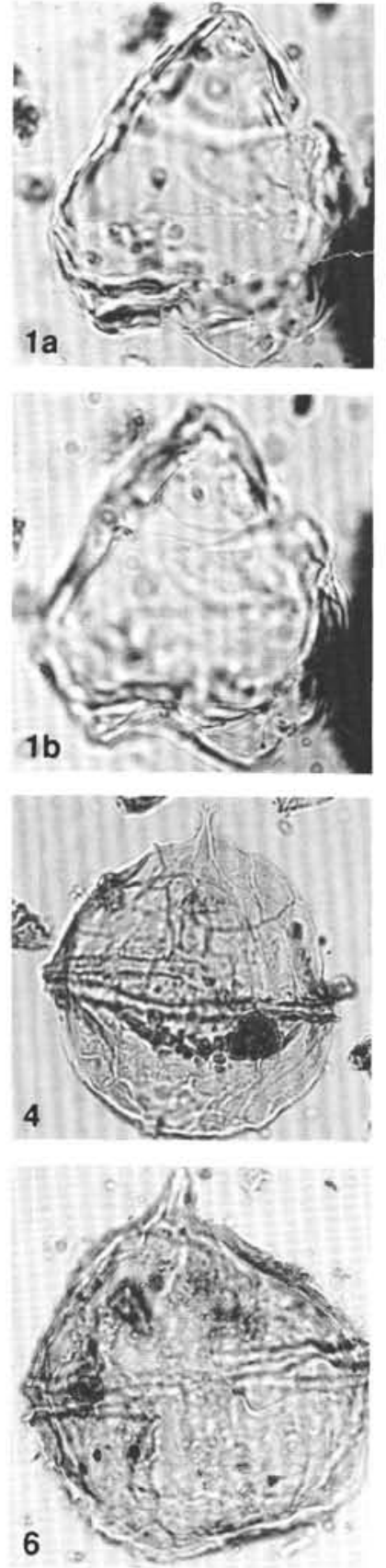
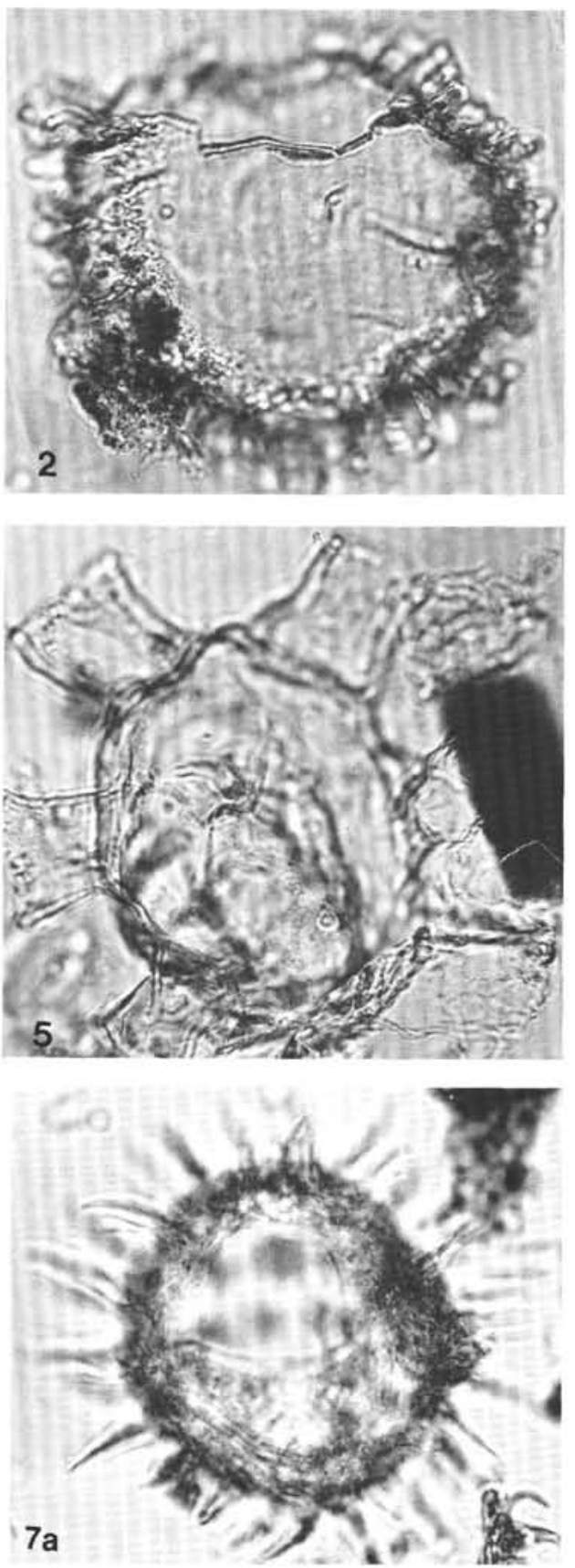
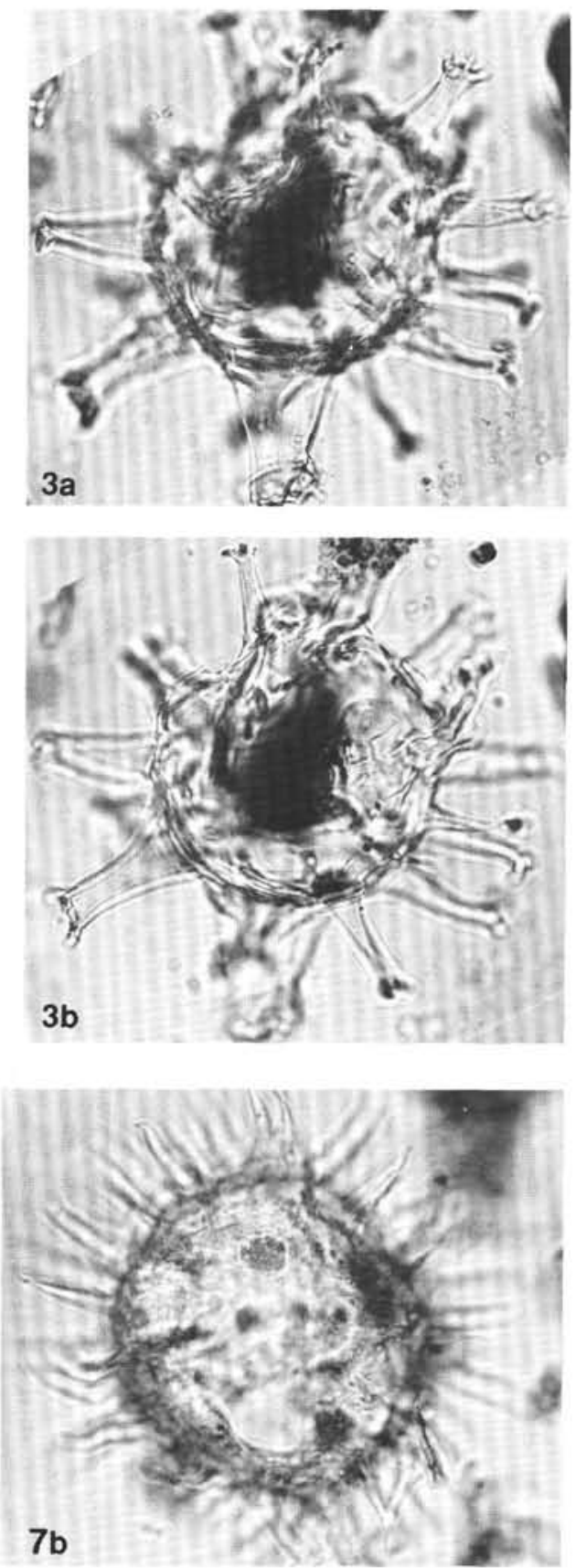

Plate 3. All magnifications at $\times 1000$, unless otherwise noted. 1. Craspedodinium sp. Sample 120-748C-79R-2, 60-63 cm; sl. S1, 30/95.8. 2. Cyclonephelium sp. Sample 120-748C-62R-4, 115-117 cm; sl. S3, 39.5/97. 3. Florentinia radiculata. Sample 120-748C-76R-CC; sl. S3, 42.5/100. 4. Cribroperidinium cooksoniae. Sample 120-748C-68R-1, 30-33 cm; sl. S3, 44.5/107; $\times 500$. 5. Florentinia mantellii. Sample 120-748C-62R-4, 115-117 cm; sl. S3, 38.7/89.1. 6. Cribroperidinium cooksoniae. Sample 120-748C-79R-2, 138-141 cm; sl. S4, 36.2/93; $\times 500$. 7. Exochosphaeridium muelleri. Sample 120-748C-78R-CC, sl. S4, 35.5/89.5. 

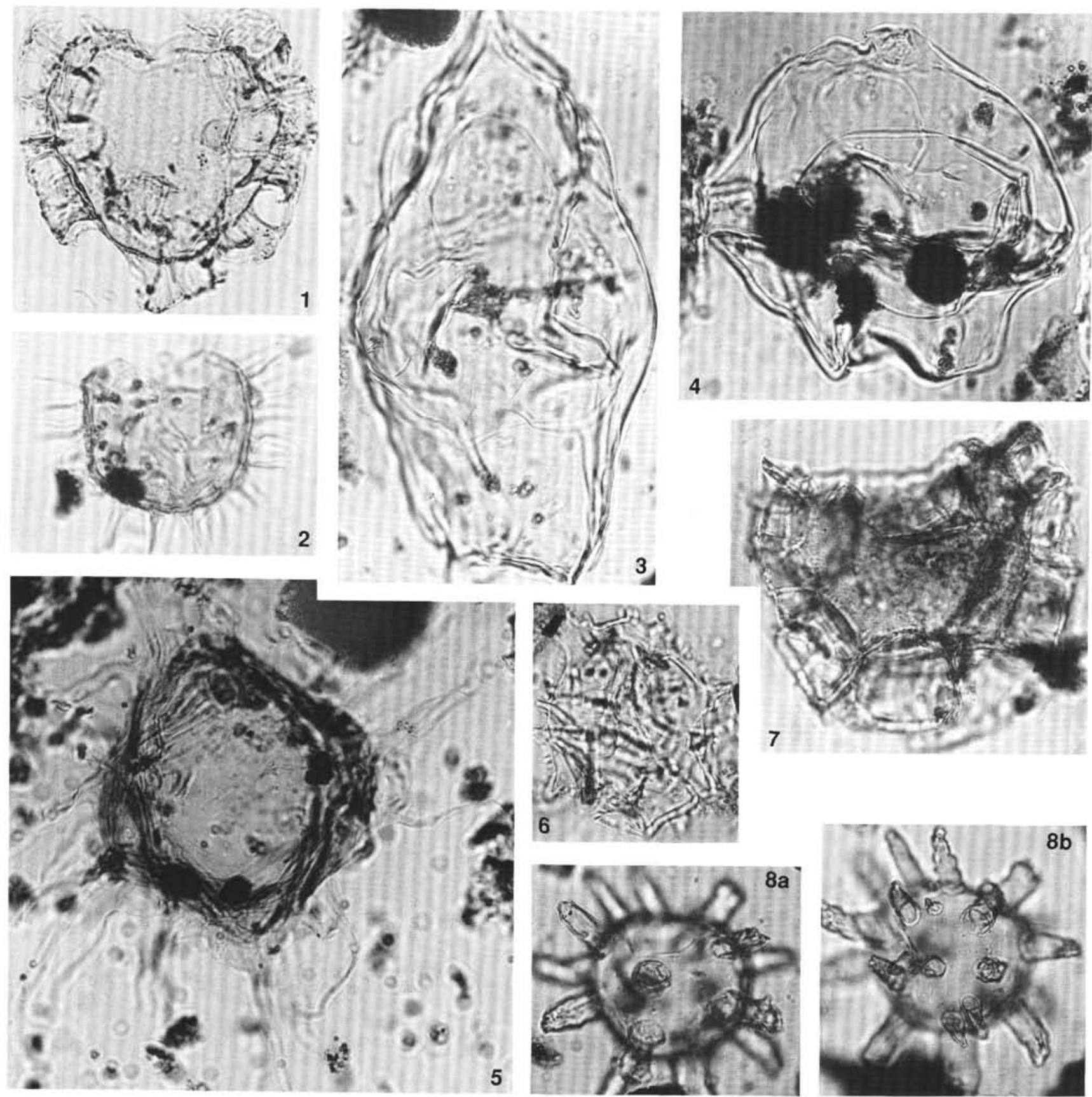

Plate 4. All magnifications at $\times 1000$, unless otherwise noted. 1. Maghrebinia membraniphora. Sample $120-748 \mathrm{C}-79 \mathrm{R}-2,138-141 \mathrm{~cm} ; \mathrm{sl}$. S4; $\times 500$. 2. Kiokansium polypes. Sample $120-748$ C-78R-CC; sl. S1, 41.9/91.5. 3. Isabelidinium belfastense. Sample 120-748C-62R-6, 52-55 $\mathrm{cm}$; sl. S1, 45.2/88.7. 4. ?Maduradinium sp. Sample 120-748C-64R-3, 78-81 cm; sl. S1, 39/91.1. 5. Hystrichodinium pulchrum. Sample 120-748C-79R-2, 60-63 cm; sl. S1, 34.1/90. 6. Microdinium setosum. Sample 120-748C-79R-2, 138-141 cm; sl. S2, 32.5/92.5. 7. Maghrebinia membraniphora. Sample 120-748C-73R-1, 57-60 cm; sl. S3, 39/96. 8. Kleithriasphaeridium tubulosum. Sample 120-748C-64R-1, 63-65 cm; sl. S2, $41 / 92.2 ; \times 500$. 

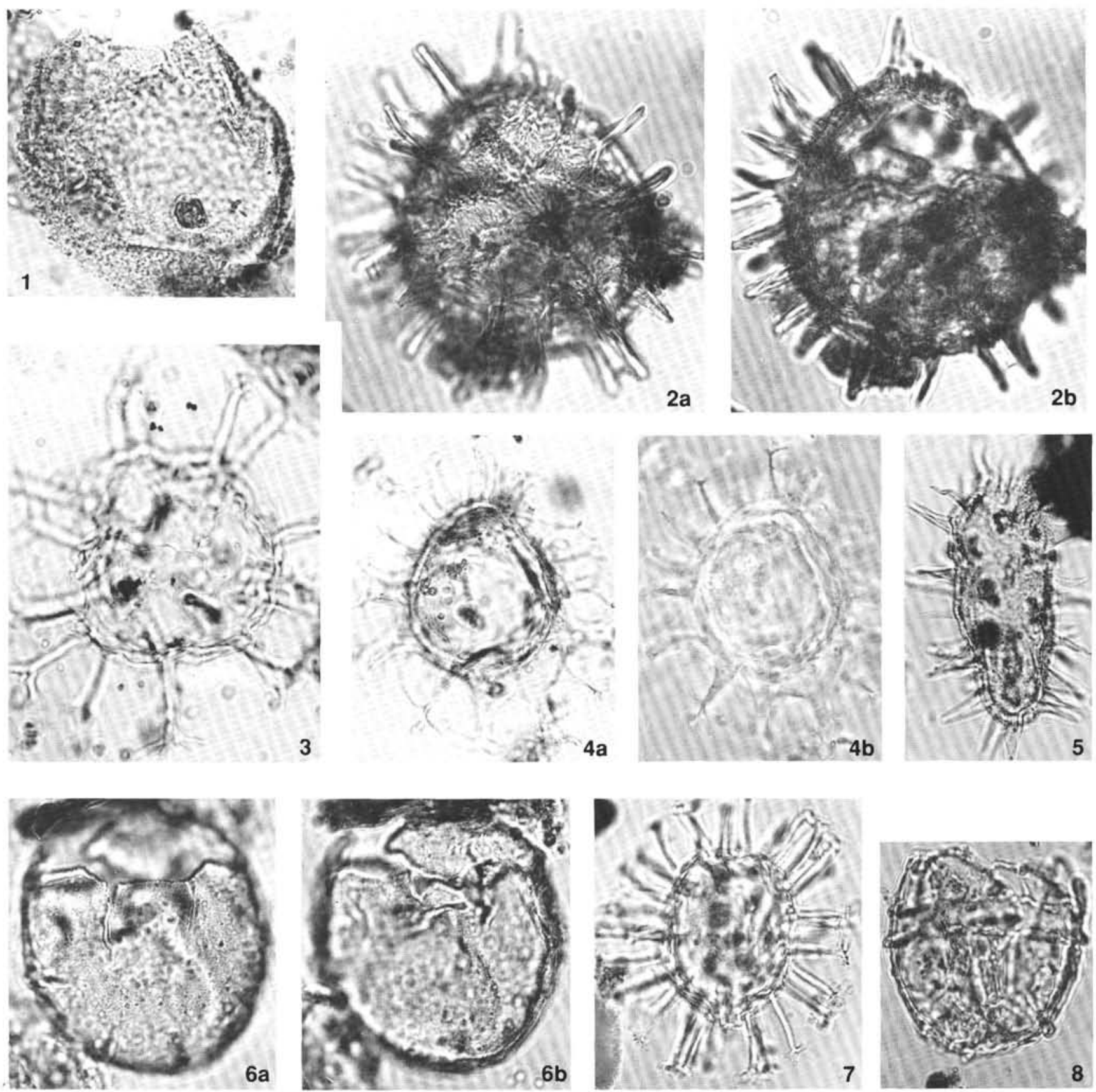

Plate 5. All magnifications at $\times 1000$, unless otherwise noted. 1. ?Kallosphaeridium granulatum. Sample 120-748C-79R-2, 138-141 cm; sl. S2, 35/90.5. 2. Pervosphaeridium pseudhystrichodinium. Sample $120-748 \mathrm{C}-68 \mathrm{R}-1,30-33 \mathrm{~cm} ; \mathrm{sl}$. S3, 44.5/92; $\times 500$. 3. Oligosphaeridium astigerum. Sample 120-748C-79R-2, 60-63 cm; sl. S1, 34.5/94.2. 4. Spiniferites wetzelii. Sample 120-748C-76R-CC, sl. S1, 38.1/96.2. 5. Prolixosphaeridium conulum. Sample 120-748C-73R-1, 57-60 cm; sl. S2, 36.3/93. 6. Ovoidinium diversum. Sample 120-748C-62R-4, 115-117 cm; sl. S3, 38.2/99. 7. Taleisphaera hydra. Sample 120-748C-79R-2, 138-141 cm; sl. S2, 43.7/92.5. 8. Microdinium omatum. Sample 120-750B-11W-CC, sl. S1, 37.5/97.1. 

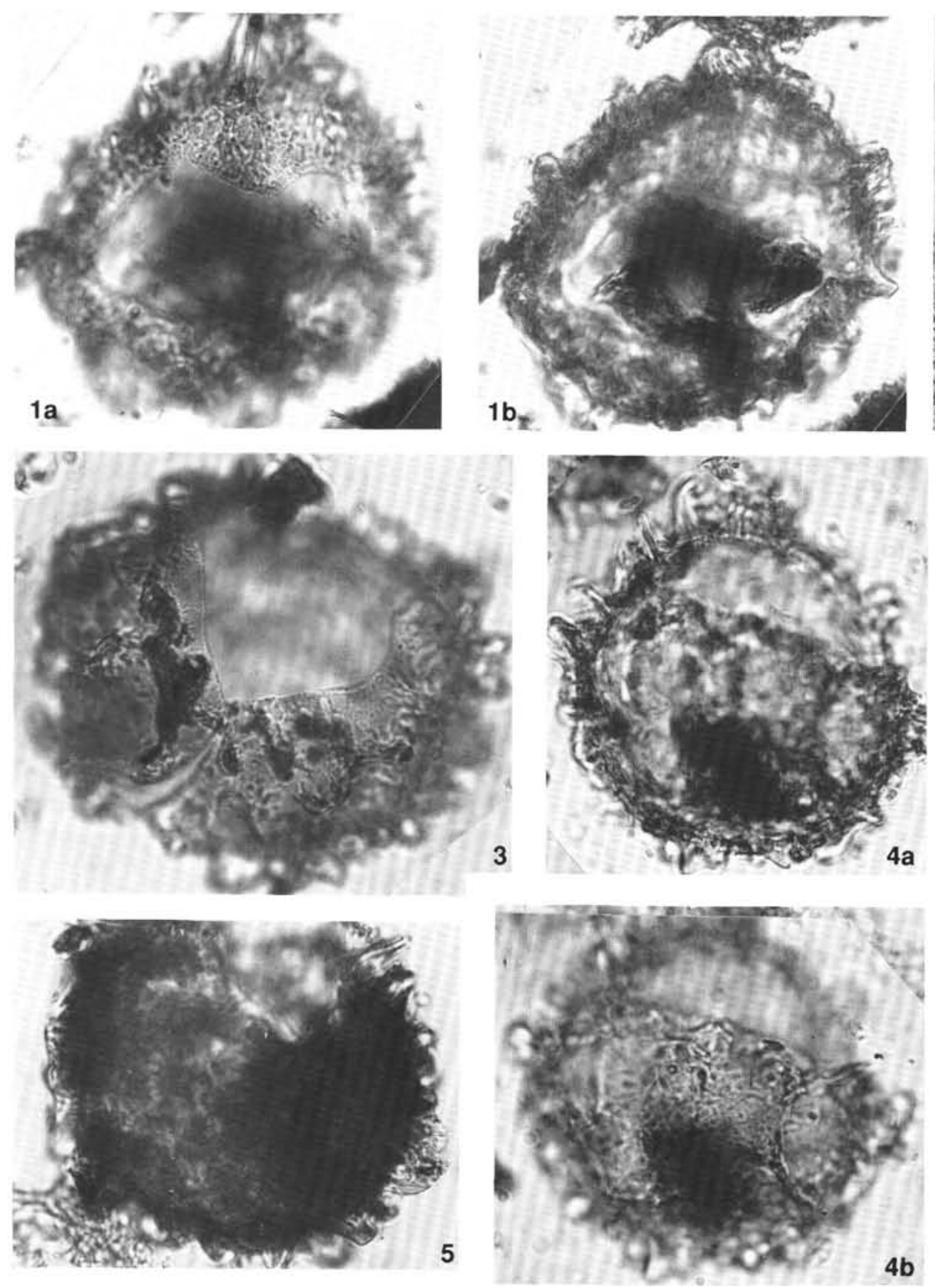
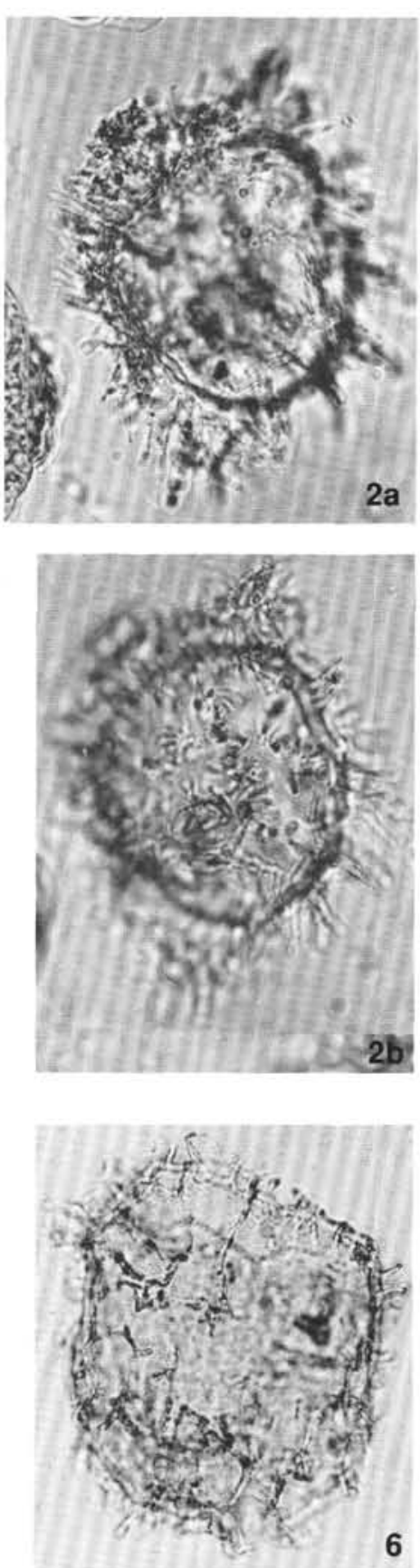

Plate 6. All magnifications at $\times 1000$, unless otherwise specified. 1. Tehamadinium $\mathrm{sp}$. A. Sample $120-748 \mathrm{C}-62 \mathrm{R}-6,52-55 \mathrm{~cm} ; \mathrm{sl}$. S3, 41.2/95. 2. Palaeohystrichophora infusorioides. Sample 120-748C-79R-2, 138-141 cm; sl. S3, 35.7/97.2. 3. Tehamadinium sp. A. Sample 120-748C-62R-6, 52-55 cm; sl. S2, 37.7/93. 4. Tehamadinium sp. A. Sample 120-748C-62R-6, 52-55 cm; sl. S1, 40/91.5. 5. Tehamadinium sp. A. Sample 120-748C-62R-6, 52-55 cm; sl. S2; 42/89.2. 6. Valensiella griphus. Sample 120-748C-79R-2, 138-141 cm; sl. $11 ; \times 500$. 

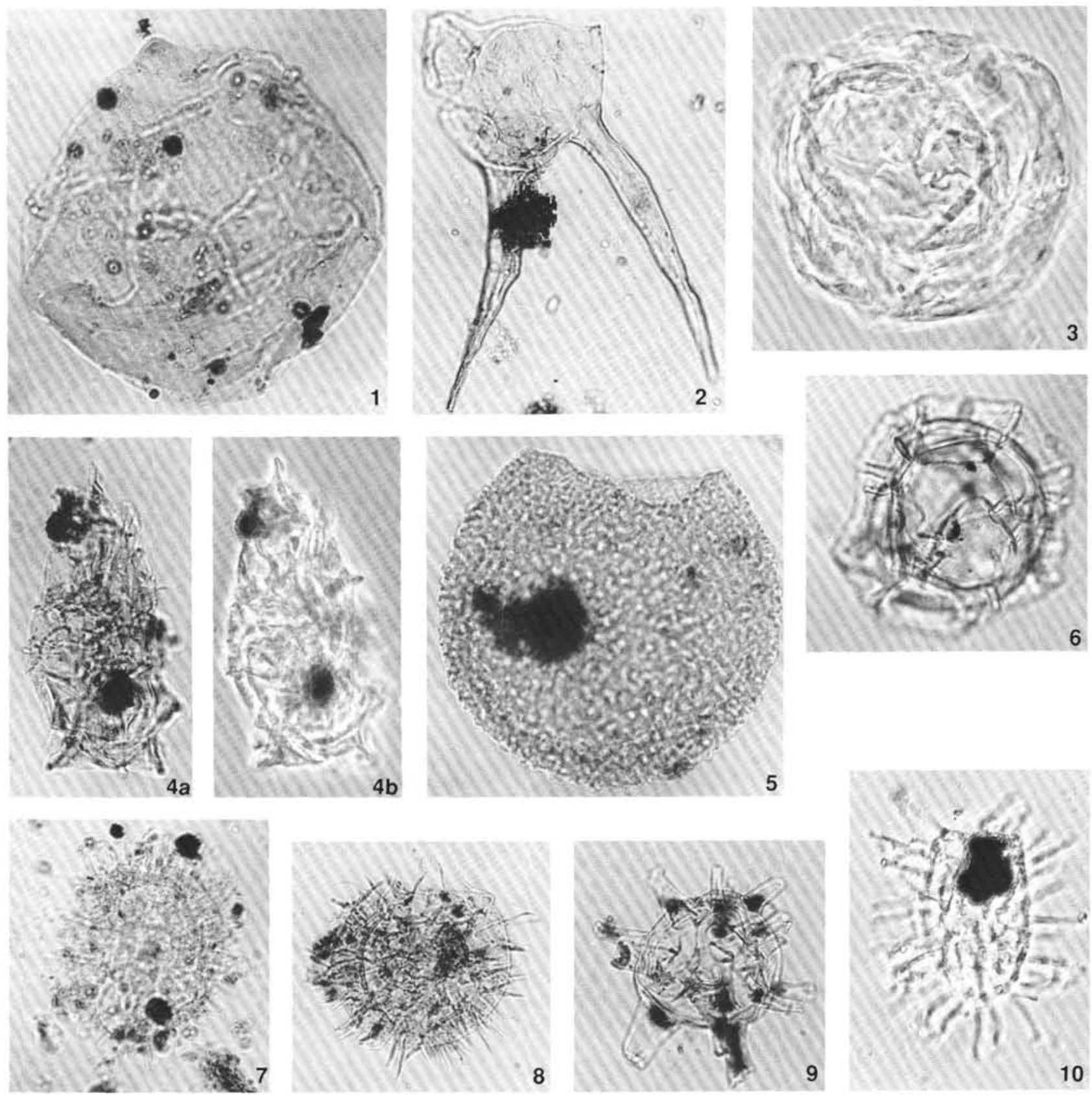

Plate 7. All magnifications at $\times 1000$, unless otherwise specified. 1. Canninginopsis colliveri. Sample 120-750B-11W-CC; sl. 5. 2. Odontochitina operculata. Sample 120-750B-11W-CC; sl. A, 46.3/91.2. 3. Disphaeria macropyla. Sample 120-750B-11W-CC; sl. 12. 4. Psaligonyaulax deflandrei. Sample 120-750B-11W-CC; sl. 17. 5. Batiacasphaera sp. Sample 120-750B-11W-CC; sl. 8. 6. Pterodinium cingulatum granulatum. Sample 120-750B-11W-CC; sl. 3. 7. Cometodinium comatum. Sample 120-750B-11W-CC; sl. 3A. 8. Cleistosphaeridium sp. Sample 120-750B-11W-CC; sl. 9; ×500. 9. Litosphaeridium siphoniphorum. Sample 120-750B-11W-CC; sl. 10. 10. Tanyosphaeridium salpinx. Sample 120-750B-11W-CC; sl. 1A, 38.7/94.4. 

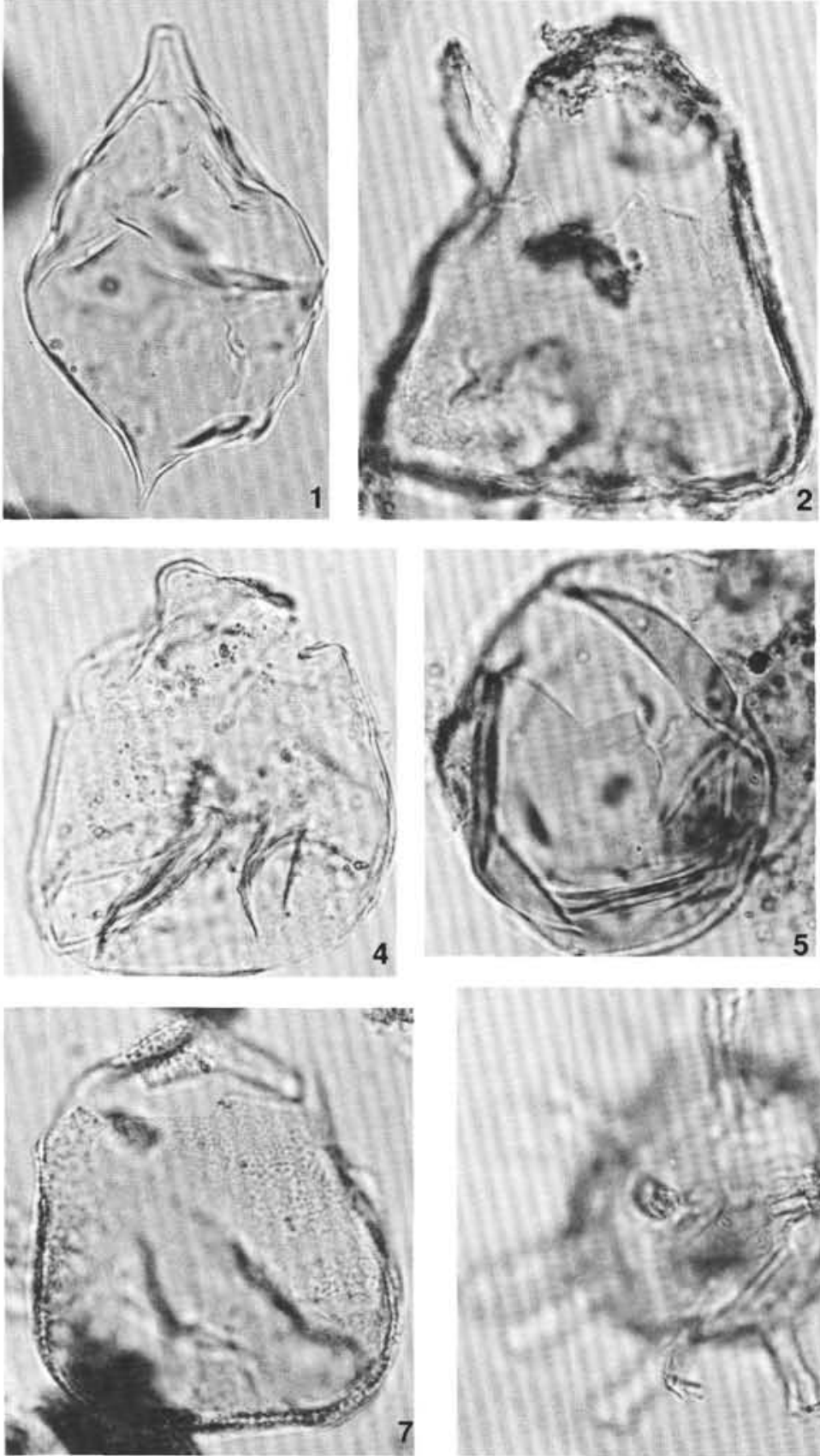
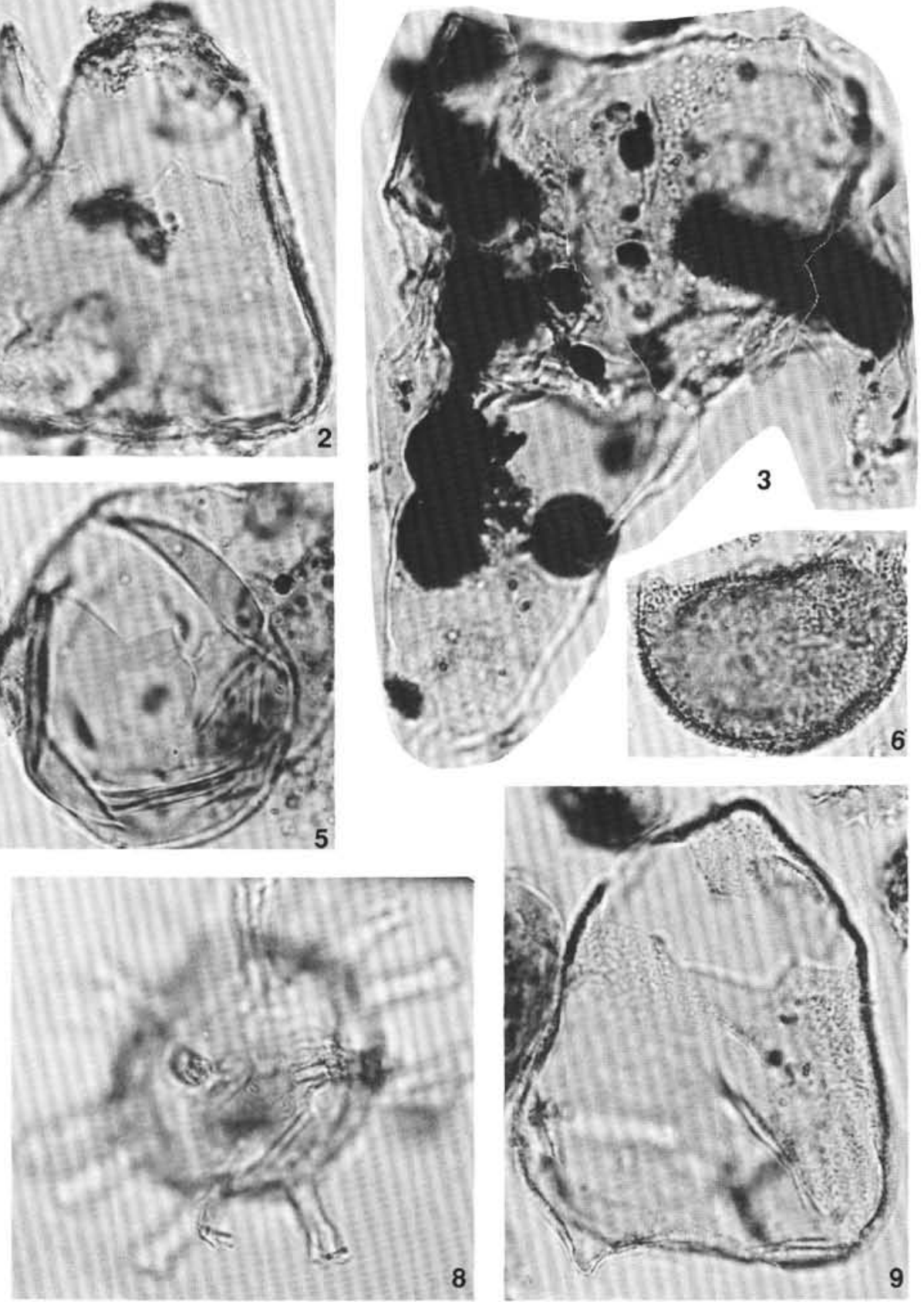

Plate 8. All magnifications at $\times 1000$. 1. Diconodinium psilatum. Sample $120-748 \mathrm{C}-68 \mathrm{R}-1,30-33 \mathrm{~cm}$; sl. S2, 36.6/91.8. 2. Trithyrodinium cf. sabulum. Sample 120-748C-62R-4, 115-117 cm; sl. S2, 37.2/98.2. 3. Xenascus cf. ceratioides. Sample 120-748C-62R-1, 52-59 cm; sl. S1, 45.7/94.2. 4. Trithyrodinium cf. sabulum. Sample $120-748 \mathrm{C}-62 \mathrm{R}-4,115-117 \mathrm{~cm}$; sl. S2, 33.2/88.8. 5. Batiacasphaera sp. Sample 120-748C-79R-2, 138-141 cm; sl. S5, 39.2/96.5. 6. Sentusidinium sp. Sample 120-748C-79R-2, 138-141 cm; sl. S8, 29.2/90. 7. Trithyrodinium cf. sabulum. Sample 120-748C-62R-4, 115-117 cm; sl. S1, 36/93. 8. Kleithriasphaeridium sp. Sample 120-748C-79R-2, 138-141 cm; sl. S5, 34/89.5. 9. Trythyrodinium cf. sabulum. Sample 120-748C-62R-4, 115-117 cm; sl. S1, 34/92. 

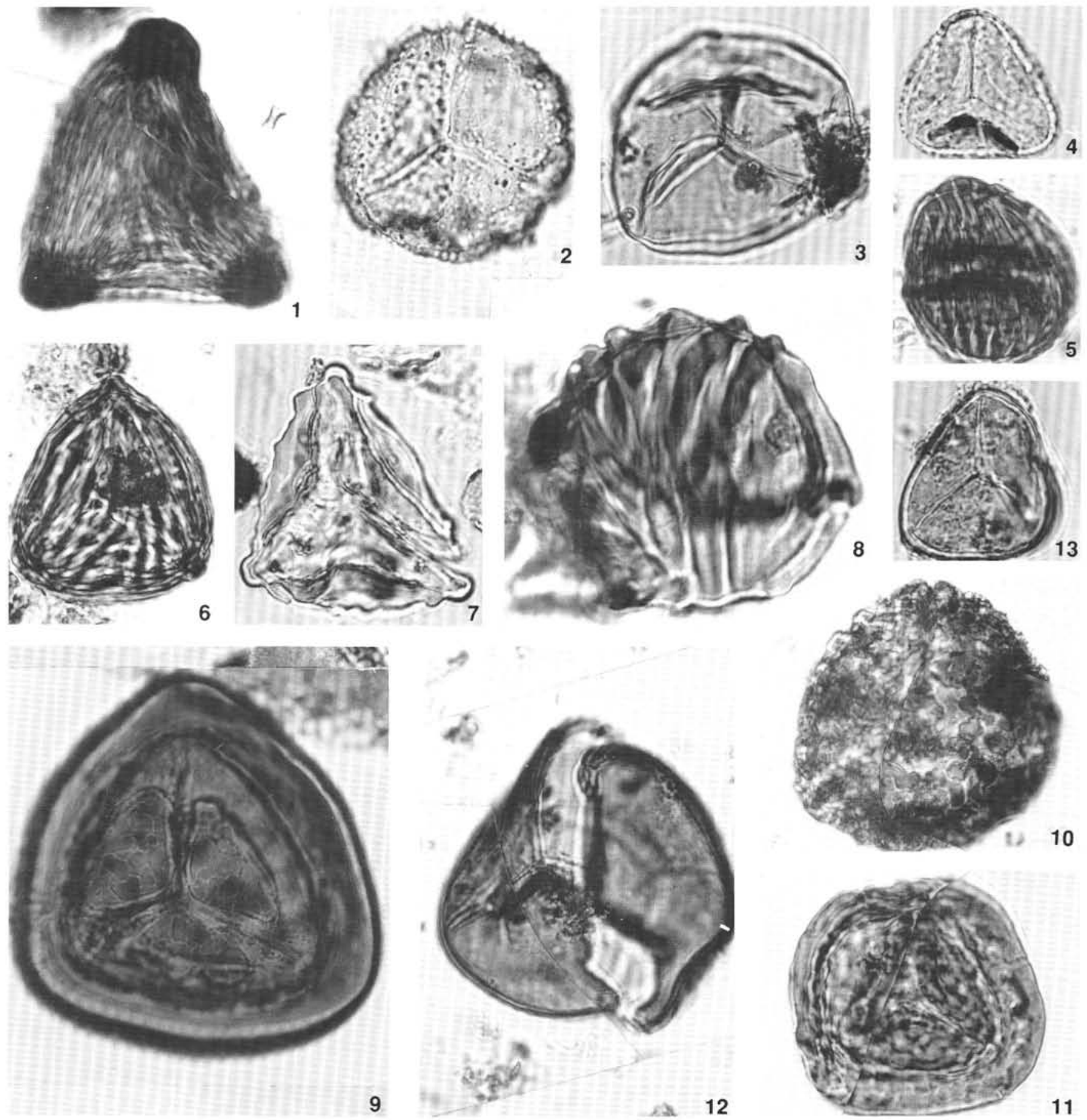

11

Plate 9. All magnifications at $\times 1000$. 1. Appendicisporites sp., cf. A. jansonii. Sample 120-748C-79R-2, 138-141 cm; sl. S5, $37.5 / 94.2$ (composite photo of a single specimen). 2. Baculatisporites comaumensis. Sample 120-748C-62R-4, 115-117 cm; S1, 37/91.5. 3. Calamospora sp. Sample 120-749C-62R-6, 52-55 cm; s1. S2, 38.9/97.7. 4. Ceratosporites distalgranulatus. Sample 120-748C-77R-CC; sl. 4. 5. Cicatricosisporites australiensis. Sample 120-748C-77R-1, 61-64 cm; sl. 1, 39/90. 6. Cicatricosisporites hughesii. Sample 120-748C-74R-CC; sl. S2, 30/94.5. 7. Clavifera triplex. Sample 120-748C-62R-4, $115-117 \mathrm{~cm}$; sl. S3, 37.5/97.8. 8. Contignisporites fornicatus. Sample 120-748C-62R-6, 52-55 cm; sl. S2, 34.5/93. 9. Cyatheacidites annulatus. Sample 120-748C-63R-CC; sl. 1A, 43.5/97.1. 10. Cyatheacidites botuliformis. Sample 120-748C78R-1, 59-62 cm; sl. 2, 35/90.3 (composite photo of a single specimen). 11. Cyatheacidites sp. A. Sample 120-748C-79R-2, 138-141 cm; sl. 9. 12. Cyathidites australis. Sample $120-748 \mathrm{C}-78 \mathrm{R}-5,105-108 \mathrm{~cm}$; sl. S2, 34/87. 13. Cyathidites minor. Sample 120-748C-62R-4, 115-117 cm; sl. $\mathrm{S} 2,32 / 91.5$. 

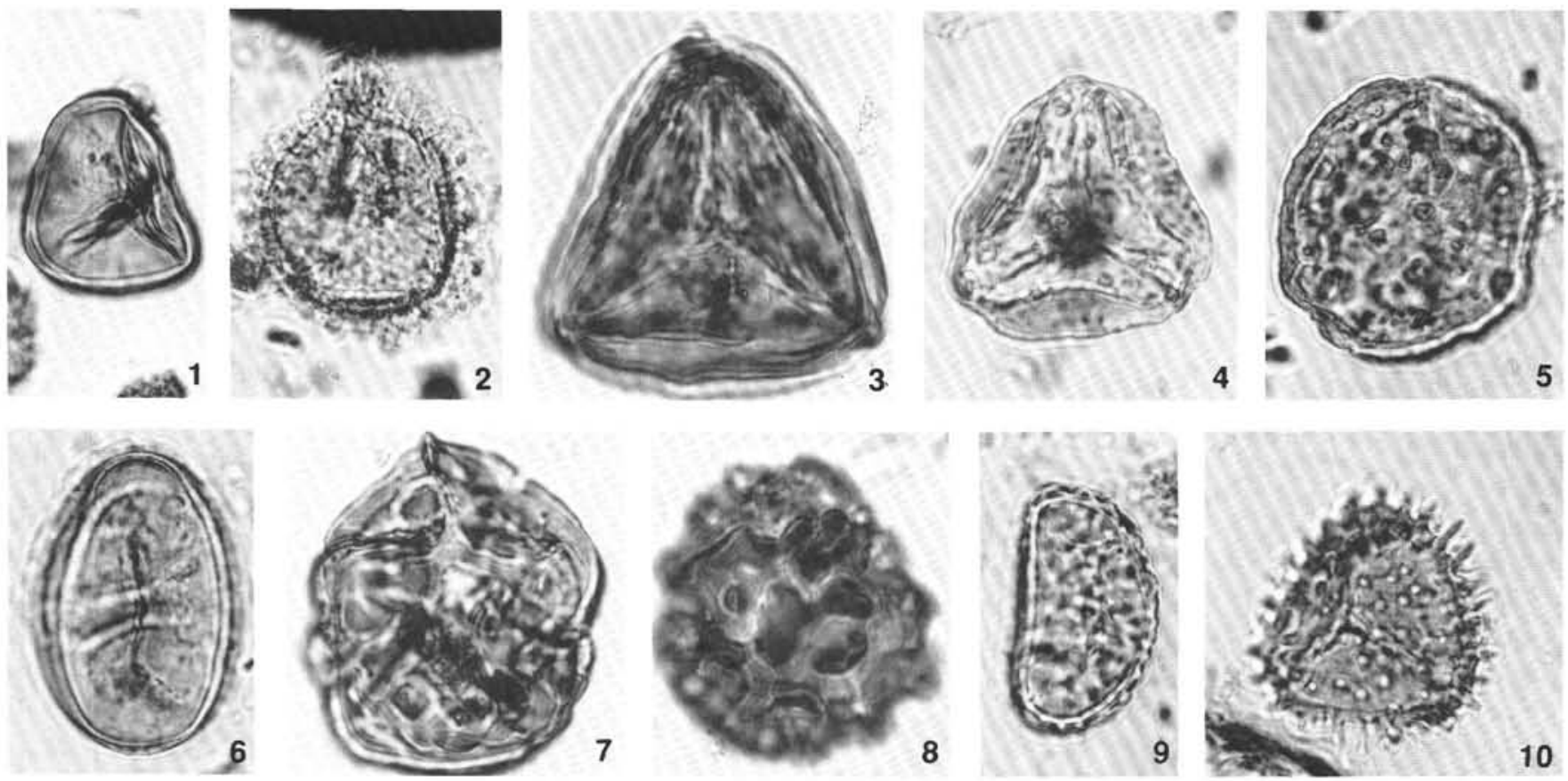

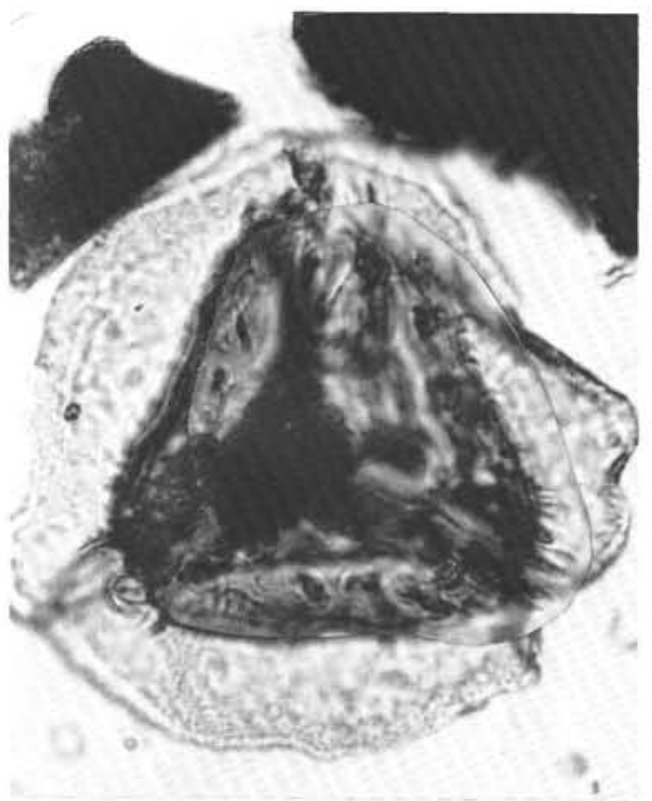

12

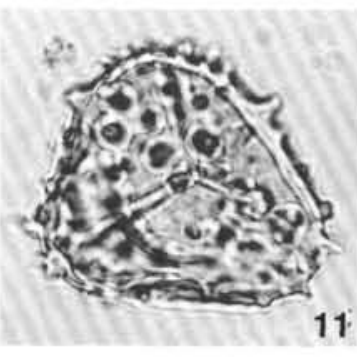

11

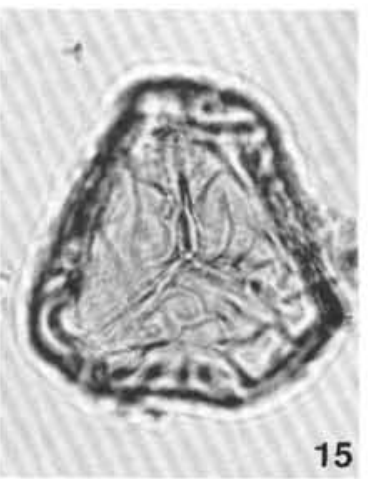

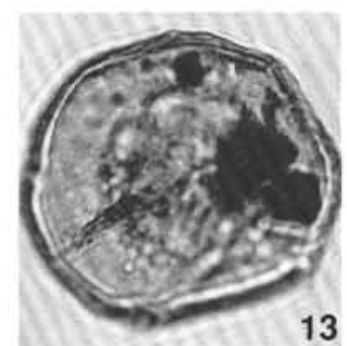
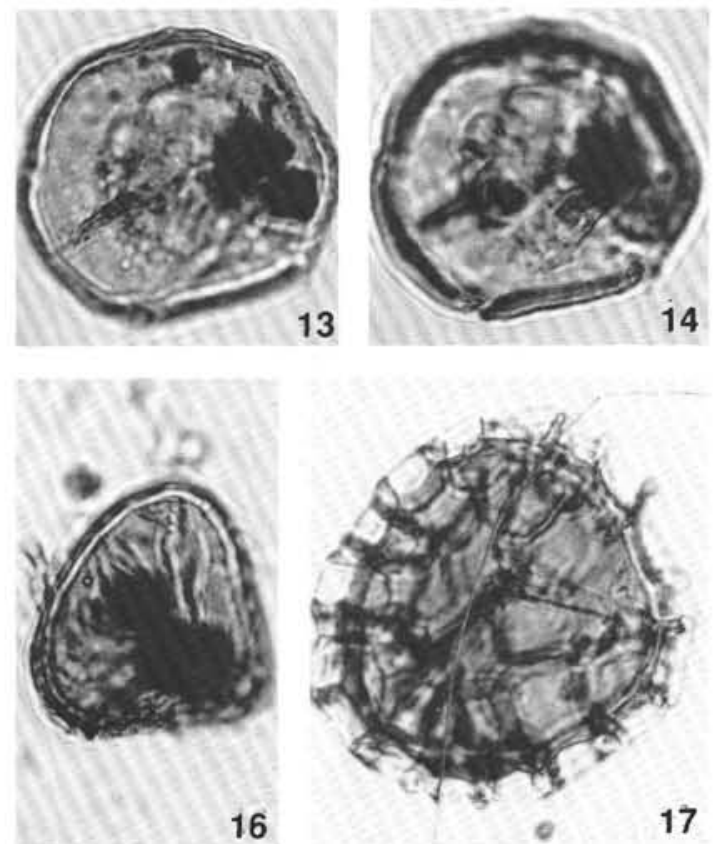

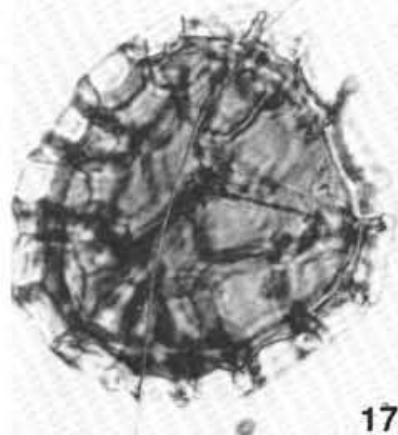

Plate 10. All magnifications at $\times 1000$. 1. Dictyophyllidites equiexinus. Sample 120-748C-78R-5, 105-108 cm; sl. S2, 41.5/87.3. 2. Dictyotosporites complex. Sample 120-748C-78R-1, 59-62 cm; sl. 2, 33.5/87.1. 3. Distaltriangulisporites sp. Sample 120-748C-79R-2, 138-141 cm; sl. 8. 4. Foveogleicheniidites confossus. Sample 120-748C-78R-5, 105-108 cm; sl. S2, 40/89.5. 5. Interulobites intraverrucatus. Sample 120-748C-79R-2, 138-141 cm; sl. S5, 37.7/94.2. 6. Laevigatosporites ovatus. Sample 120-748C-62R-4, 115-117 cm; sl. S2, 34.5/97.5. 7. Leptolepidites major. Sample 120-748C-79R-2, 138-141 cm; sl. S4, 39.1/88.2. 8. Leptolepidites verrucatus. Sample 120-748C-62R-4, 115-117 cm; sl. S1, 38/93.5. 9. Microfoveolatosporites canaliculatus. Sample 120-748C-78R-1, 59-62 cm; sl. 2, 38.5/97.8. 10. Neoraistrickia equalis. Sample 120-748C-79R-2, 138-141 cm; sl. 5. 11. Neoraistrickia truncata. Sample 120-748C-79R-2, 138-141 cm; sl. S6, 31.5/97.2. 12. Perotrilites majus. Sample 120-748C-73R-6; sl. S1, 40.5/94 (composite photo of a single specimen). 13. Polycingulatisporites clavus, proximal focus showing trilete mark. Sample 120-748C-72R-1, 70-73 cm; sl. S2, 33.5/90.7. 14. Polycingulatisporites clavus, distal focus showing circumpolar ring of verrucae. Sample 120-748C-72R-1, 70-73 cm; sl. S2, 33.5/90.7. 15. Reticulisporites (sensu Uwins and Batten, 1988) sp. A. Sample 120-748C-68R-1, 30-33 cm; sl. S3, 39.5/103. 16. Reticulisporites sp. B. Sample 120-748C-62R-6, 52-55 cm; sl. S1, 37.7/97.5. 17. Retitriletes austroclavatidites. Sample 120-748C-77R-CC; sl. S1, 47.2/92.2 (composite photo of a single specimen). 

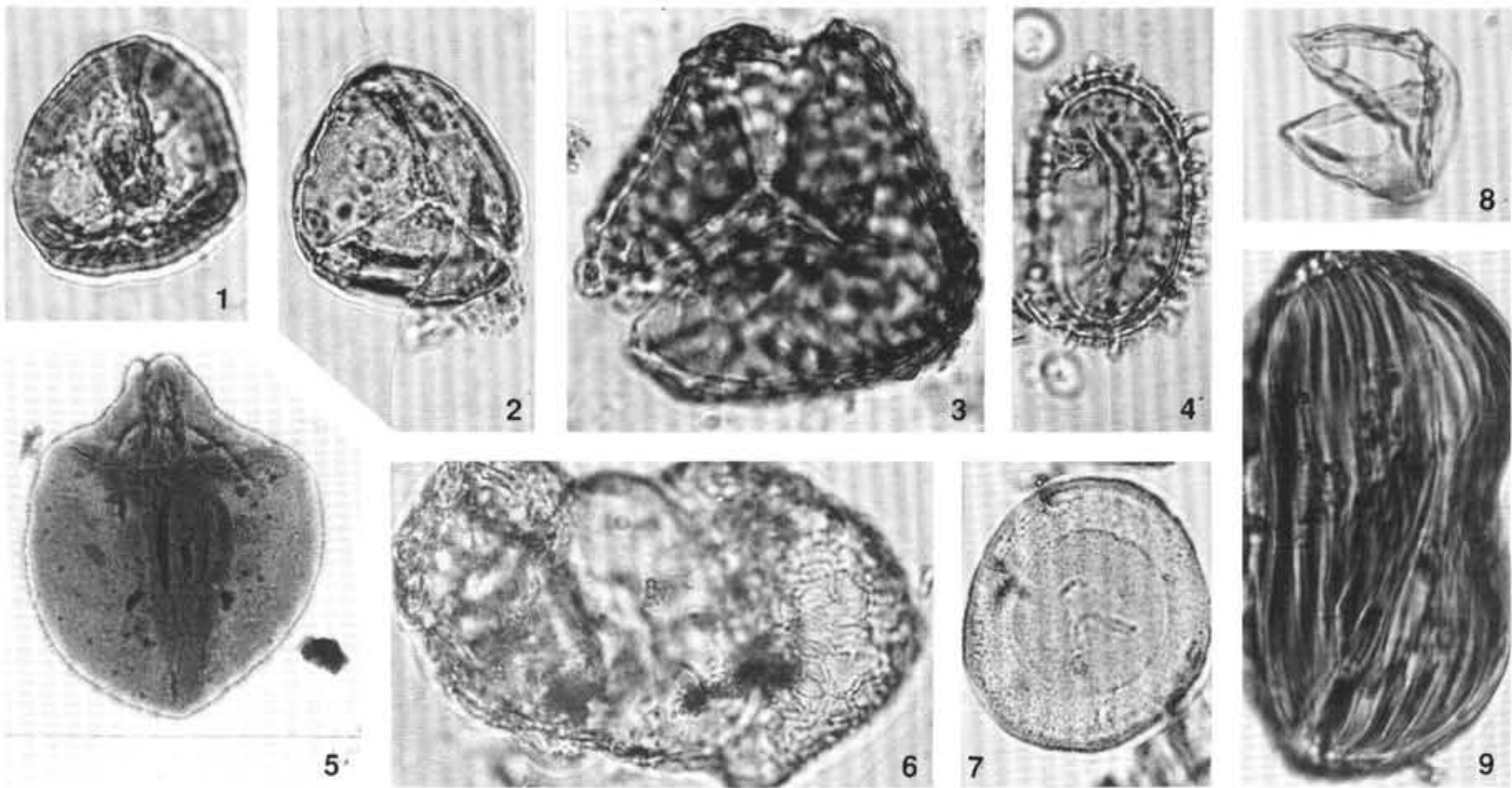

5
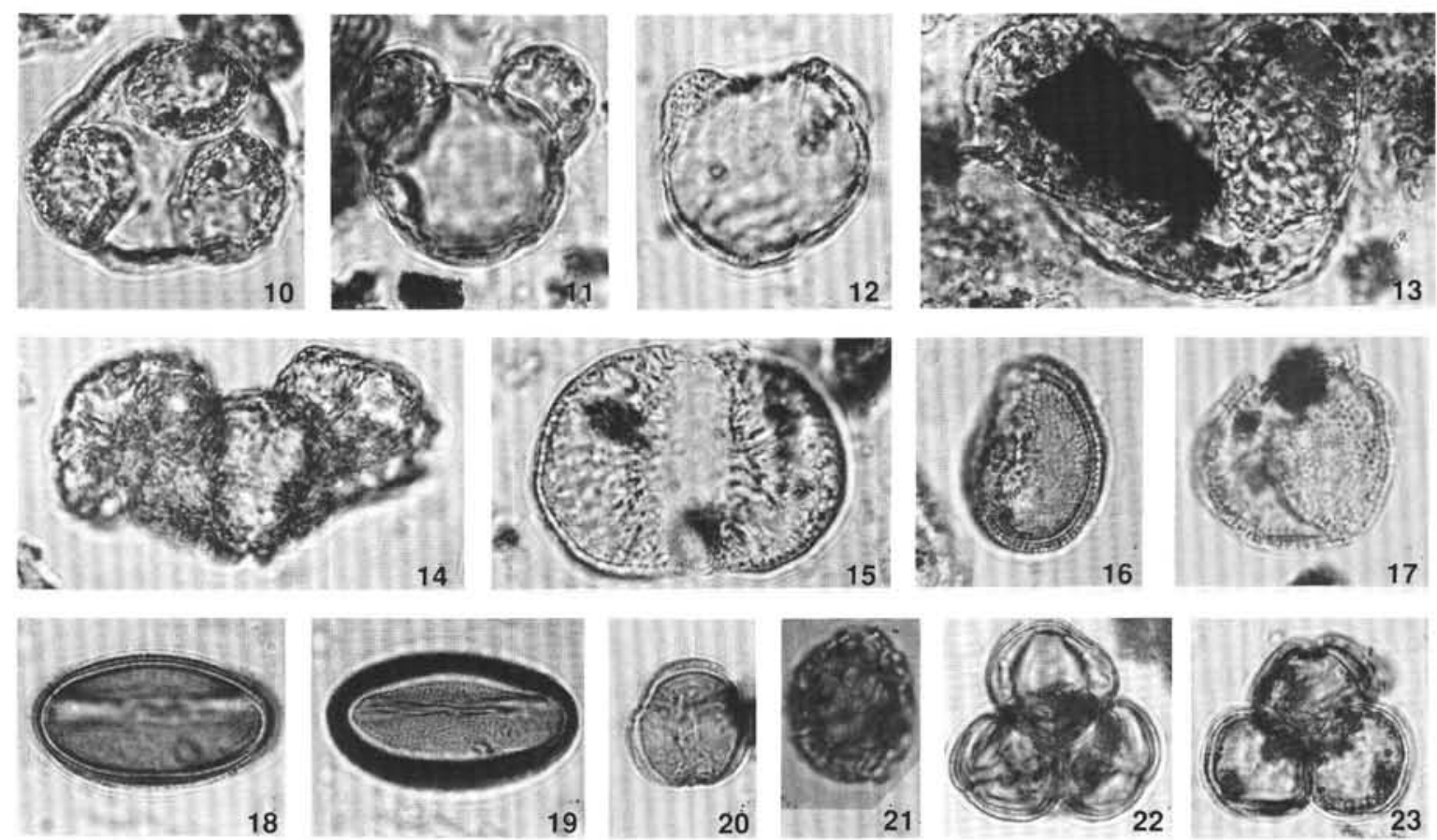

Plate 11. All magnifications at $\times 1000$. 1. Stereisporites pocockii. Sample $120-748 \mathrm{C}-62 \mathrm{R}-4,115-117 \mathrm{~cm}$; sl. S3, 39.2/95. 2 . Stoverisporites microverrucatus. Sample 120-748C-62R-4, 115-117 cm; sl. S2, 36/99.2 (composite photo of a single specimen). 3. Triletes tuberculiformis. Sample 120-748C-62R-6, 52-55 cm; sl. S1, 40/87.1. 4. Tuberculatosporites sp. Sample 120-748C-78R-CC; sl. S1, 42.5/99.2. 5. Megaspore. Sample 120-748C-78R-CC; sl. S1, 39/92.2. 6. Alisporites similis. Sample 120-748C-62R-4, 115-117 cm; sl. S3, 45.5/93.5. 7. Corollina sp., Sample 120-748C-79R-2, 138-141 cm; sl. S6, 41/91.2. 8. Cupressacites sp. Sample 120-748C-77R-CC; sl. S3, 34.2/90.5. 9. Ephedripites sp. Sample 120-748C-79R-2, 138-141 cm; sl. S5, 36/88.5. 10. Microcachryidites parvus, the trisaccate form. Sample 120-748C-62R-4, $115-117 \mathrm{~cm}$; $\mathrm{sl}$. S3, 42.2/102. 11. Microcachryidites parvus, the bisaccate form. Sample 120-748C-62R-6, 52-57 cm; sl. S1, 39.2/96.5. 12. Microcachryidites sp., the bisaccate form (trisaccate form not shown). Sample 120-748C-62R-6, 52-55 cm; sl. S1, 39/91.6. 13. Podocarpidites sp. A. Sample 120-748C-75R-1, 58-61 cm; sl. S1, 43/88.9. 14. Podocarpidites sp. B. Sample 120-748C-62R-4, 115-117 cm; sl. S2, 35.5/96.6. 15. Vitreisporites pallidus. Sample 120-748C-70R-1, 63-67 cm; sl. 3, 43/89.3. 16. Clavatipollenites hughesii. Sample 120-748C-65R-1, $46-50 \mathrm{~cm}$; sl. S2, 39.2/93.5. 17. Clavatipollentes $\mathrm{sp} .8$ (sensu Dettmann, 1973). Sample 120-748C-77R-CC; sl. S1, 42.5/90.5. 18. Liliacidites sp., mid-focus showing the pollen wall. Sample 120-748C-62R-4, 115-117 cm; sl. S1, 43/91. 19. Liliacidites sp., proximal focus showing the sulcus. Sample 120-748C-62R-4, 115-117 cm; sl. S1, 43/91. 20. Nyssapollenites lanosus. Sample 120-748C-76R-CC; sl. S1, 36.5/92. 21. Retimonocolpites peroreticulatus. Sample 120-748C-78R-CC; sl. S1, 28.2/88.6. 22. Tricolporopollenites sp. A. Sample 120-748C-76R-CC; sl. S1, 40/99. 23. Tricolporopollenites sp. B. Sample 120-748C-79R-1, 55-58 cm; sl. S1, 38.2/98.5. 